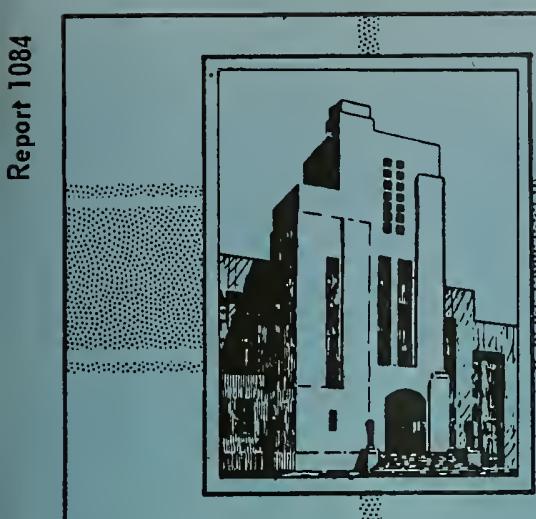

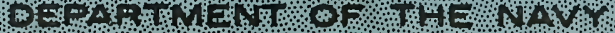 \\ MAVD THVOR WODEL BASIN
}

HYDROMECHANICS

0

AERODYNAMICS

STRUCTURAL MECHANICS

O

APLLIED EEMATICS
A STUDY OF THE SEA BEHAVIOR OF A MARINER-CLASS SHIP EQUIPPED WITH ANTIPITCHING BOW FINS

by

Ulysses A. Pournaras

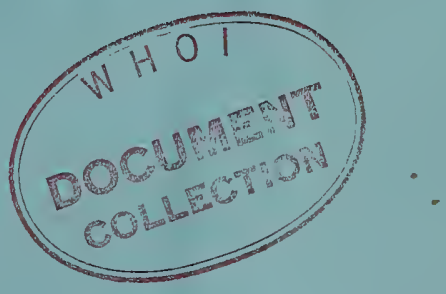

HYDROMECHANICS LABORATORY

RESEARCH AND DEVELOPMENT REPORT

October 1958

Report 1084 


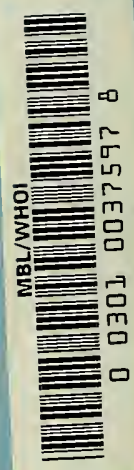




\section{A STUDY OF THE SEA BEHAVIOR OF A MARINER-CLASS SHIP EQUIPPED WITH ANTIPITCHING BOW FINS}

by

Ulysses A. Pournaras

October 1958

Report 1084 


\section{TABLE OF CONTENTS}

\section{Page}

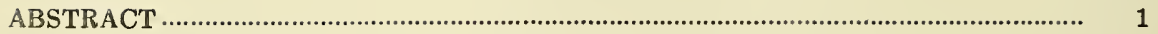

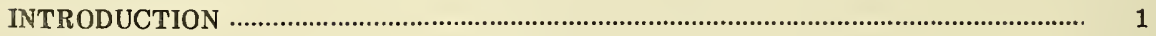

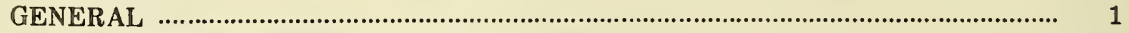

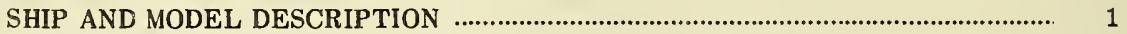

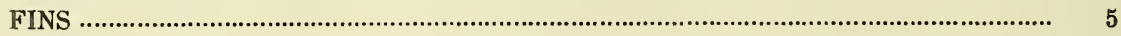

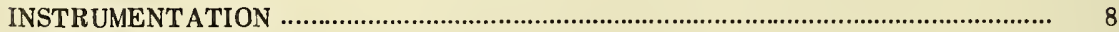

TEST PROGRAM

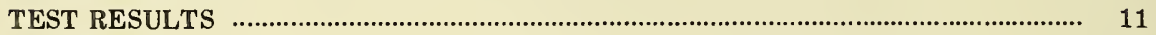

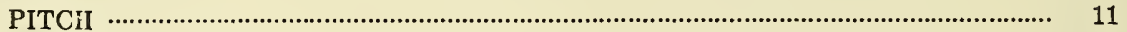

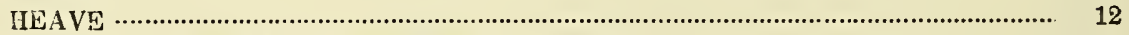

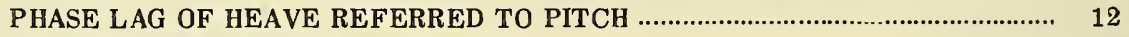

POINT OF MINIMUM VERTICAL MOTION ………......................................................... 13

VERTICAL MOTION AND ACCELERATION .............................................................. 13

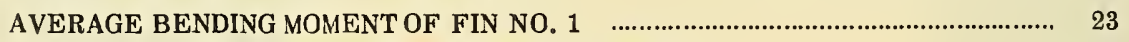

COMPARATIVE PITCH REDUCTION OF FINS TESTED ……………………............ 23

SUMMARY OF TEST RESULTS ……………………...................................................... 27

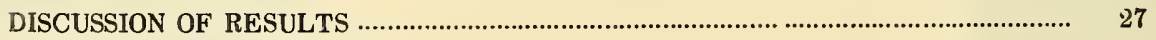

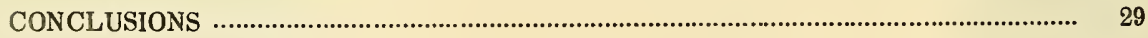

REFERENCES 


\section{LIST OF ILLUSTRATIONS}

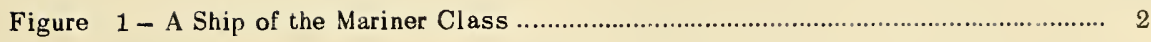

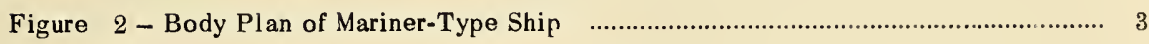

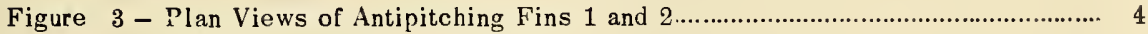

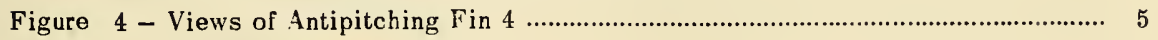

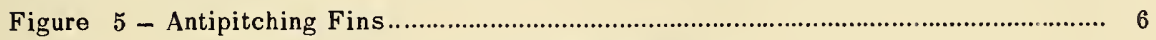

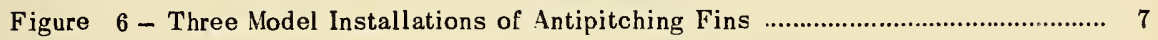

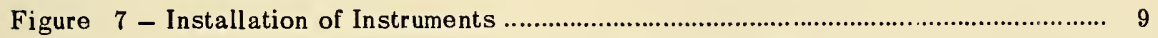

Figure 8 - Experimental Pitch Amplitudes As a Function of Wave Height ................... 12

Figure 9 - Experimental Heave Amplitudes As a Function of Wave Height.................. 13

Figure 10 - Experimental Phase Relationship Between Heave and Pitch ...................... 14

Figure 11 - Computed Location of Point of Minimum Vertical Motion ........................... 14

Figure 12 - Computed Amplitude of Vertical Motion Along Length of Ship .................... 15

Figure 13 - Computed Amplitude of Vertical Acceleration Along Length of Ship ............ 19

Figure 14 - Experimental Average Bending Moments Experienced in Waves by Fin No. 1, 7 Feet off Centerline ......................................................... 24

Figure 15 - Comparative Performance of Various Fin Configurations Tested ................ 25

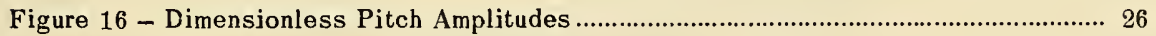

Figure 17 - Dimensionless Heave Amplitudes $\quad$...................................................... 26

Figure 18 - Phase Lag of Heave Referred to Pitch................................................... 27

\section{LIST OF TABLES}

Table 1 - Principal Characteristics of Mariner-Type Ship and TMB Model $4414 \ldots \ldots \ldots \ldots . .1$

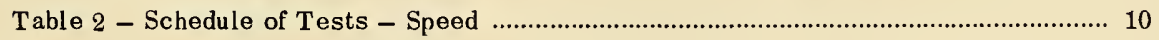

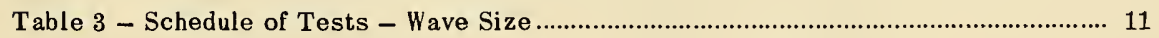

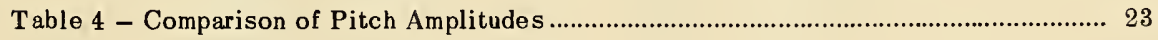




\section{NOTATION}

$\begin{array}{ll}F_{n} & \text { Froude number } \\ g & \text { Acceleration due to gravity } \\ h & \text { Wave height measured from trough to crest, } 2 r_{m} \\ L & \text { Ship length } \\ L C G & \text { Longitudinal center of gravity } \\ r_{m} & \text { Wave amplitude } \\ T & \text { Period } \\ V & \text { Ship speed } \\ Z & \text { Dimensionless heave, } z_{m} / r_{m} \\ z_{m} & \text { Heave amplitude } \\ \lambda & \text { Wave length } \\ \Psi & \text { Dimensionless pitch, } \psi_{m} / \theta_{m} \\ \omega_{e} & \text { Frequency of encounter in waves }\end{array}$




\section{ABSTRACT}

The results of model tests performed to determine the feasibility of reducing the pitching motion of the Mariner-type ship by means of fixed antipitching fins at the bow are presented. A 20 -foot self-propelled model representing the final design of the Mariner-type ship was tested in waves with four antipitching fin configurations. Data are presented for both model and ship and are summarized in dimensionless form. The data are also used to compute the effect of the fins on the vertical motion and acceleration along the length of the ship.

\section{INTRODUCTION}

\section{GENERAL}

A self-propelled model of the Mariner-type ship with and without antipitching bow fins has been tested in waves at the David Taylor Model Basin. Four fins were fitted to a Mariner model to determine the pitch reduction as a function of plan characteristics.

The model, fins, and instrumentation used for the tests are described, and the experimental results are presented and discussed.

\section{SHIP AND MODEL DESCRIPTION}

TMB Model 4414 with a linear ratio of 24.175 , representing the final design of the Mariner-type ship, was used for the tests. The principal characteristics of the ship and the model are given in Table 1.

\section{TABLE 1}

Principal Characteristics of Mariner-Type Ship and TMB Model 4414

\begin{tabular}{|l|c|c|}
\hline \multicolumn{1}{|c|}{ Item } & Ship & Model \\
\hline Length, 0.A. & $563 \mathrm{ft}-73 / 4 \mathrm{in.}$ & $23.30 \mathrm{ft}$ \\
Length, B.P. & $528 \mathrm{ft}-6$ in. & $21.85 \mathrm{ft}$ \\
Length, 25 ft -0 in. WL & $520 \mathrm{ft}-0$ in. & $21.34 \mathrm{ft}$ \\
Beam, Max. Molded & $76 \mathrm{ft}-0$ in. & $3.14 \mathrm{ft}$ \\
Draft, Load Line & $29 \mathrm{ft}-10 \mathrm{l} / 16 \mathrm{in}$. & $1.24 \mathrm{ft}$ \\
Displacement, Load Line & 21,093 tons & $3,252 \mathrm{lb}$ \\
Block Coeff., $C_{B}$ & 0.613 & 0.613 \\
Load Waterplane Coeff., $C_{W}$ & 0.724 & 0.724 \\
Design Speed & 20 knots & - \\
\hline
\end{tabular}


The model had been usad in previous resistance tests and was modified to coniorm with the sheer forward of amidships. The forecastle deck and bulwark, properly scaled, were also added to the model. A solid watertight deck cover was provided throughout the length of the model.

A photograph of the ship is presented in Figure 1; the body plan in Figure 2.

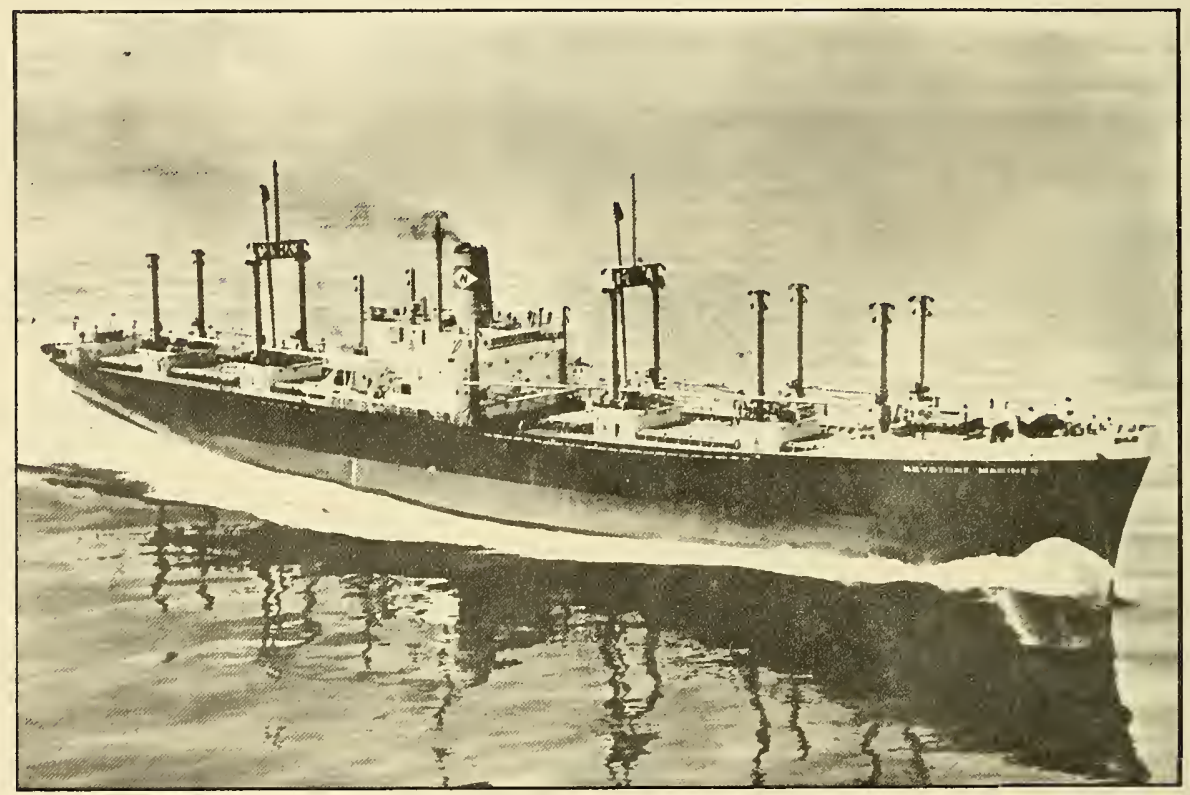

Figure 1 - A Ship of the Mariner Class 


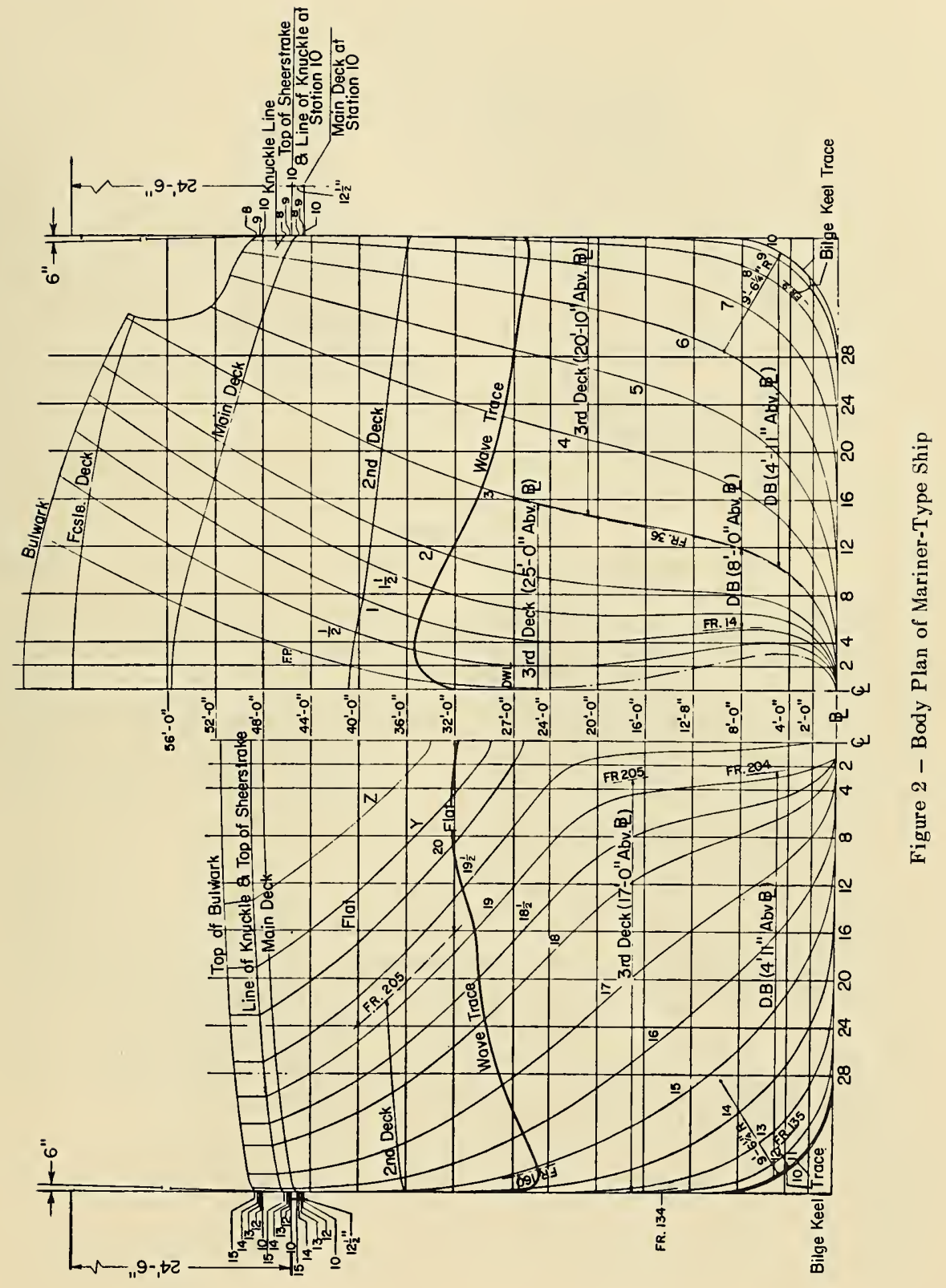




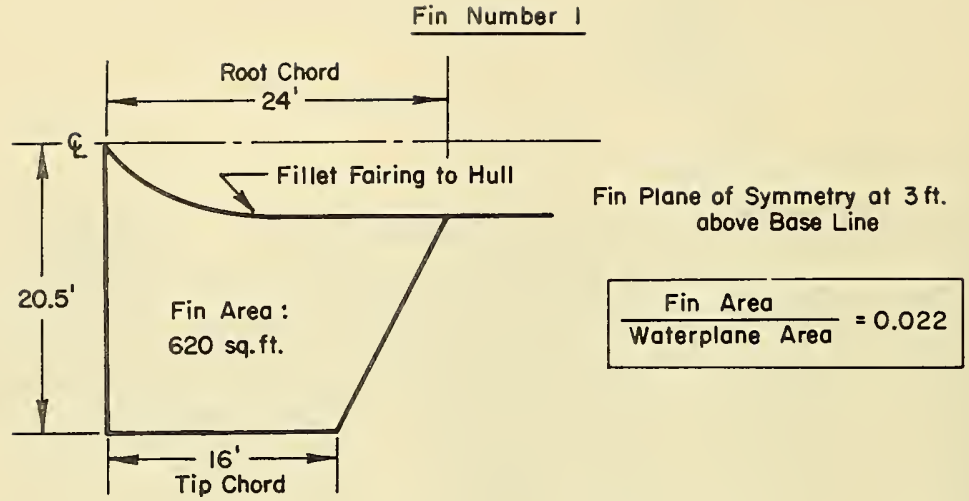

Fin Number 2

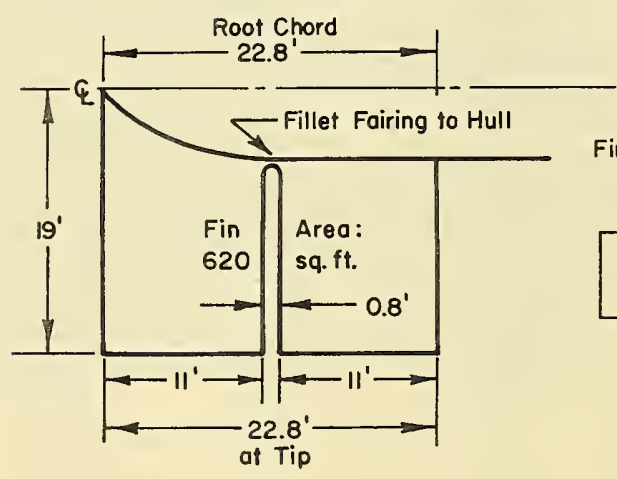

Fin Plane of Symmetry at $3 \mathrm{ft}$. above Base Line

$\frac{\text { Fin Area }}{\text { Waterplane Area }}=0.022$

Fin Number $2 s$ - Obtained from Fin Number 2, by cutting $5 \mathrm{ft}$. off each tip, $P Q S$.

Tips off Centerllne: $14 \mathrm{ft}$.

Fin Area : 400 sq.ft. $\frac{\text { Waterplane Areo }}{20.014}$

Fin Number $2 \mathrm{~h}$ - Obtained from Fin Number $2 \mathrm{~s}$, by drilling two $11 / 2 \mathrm{ft}$. diameter holes $2 \mathrm{ft}$. aft of leading edge of fwd fin and two $11 / 2 \mathrm{ft}$. diameter holes $2 \mathrm{ft}$. fwd of troiling edge of aft fin. Area and span of fins not changed.

Figure 3 - Plan Views of Antipitching Fins 1 and 2 

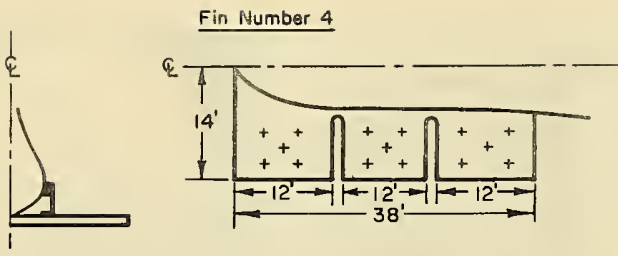

Fins separated by $1 \mathrm{ft}$.

Upper surface of fin tangent to baseline.

Fin Area: $640 \mathrm{sq} \mathrm{ft}$.

$\frac{\text { Fin Area }}{\text { Waterplane Area }}=0.023$

$\mathrm{F}$ in Number $4 \mathrm{~h}$

Obtained from Fin Number 4, by drilling five 1-ft diameter holes on each fin as indicated in sketch.

Figure 4 - Views of Antipitching Fin 4

\section{FINS}

The program consisted in testing several antipitching fins to compare their relative performance. The difference among the various configurations tested was one of plan geometry. In profile section all fins were essentially flat plates with faired leading and trailing edges. The intersections of the fins with the hull were fillet-faired. The principal characteristics of the fins are shown in Figures 3 and 4 . Figures 5 and 6 show photographs of the various fins as installed on the model. Following is a description of the four types tested.

Fin No. 1 Swept Forword. This fin had a leading edge normal to the direction of advance, and a swept forward trailing edge. The purpose of the sweep was to reduce the load near the tips and, therefore, the bending moment at the root. The thickness of the fin was $5 / 8$ inch, corresponding to the apparently unrealistic full-scale thickness of 15 inches. The leading edge of the fin was at a distance aft of the forward perpendicular corresponding to 2.38 feet full scale. The chord plane of symmetry was at the ship's 3 -foot waterline. The span of the fin, tip to tip, corresponded to nearly 41 feet. The plan area outboard of the hull was 2.2 percent of the load waterplane area. Fences were installed at both tips of the fin. These extended 18 inches full scale above and below the upper and lower surface of the fin.

Fin No. 2 Twin Configurotion. This configuration was rectangular, the span measurement corresponding to 38 feet full scale. The chord plane of symmetry was as in the previous case. The two fins making up the configuration were identical, had a chord corresponding to 11 feet full scale and were separated by a distance corresponding to 9.6 feet. The purpose of the separation was to facilitate the flow around the fin by offering a passage through the 


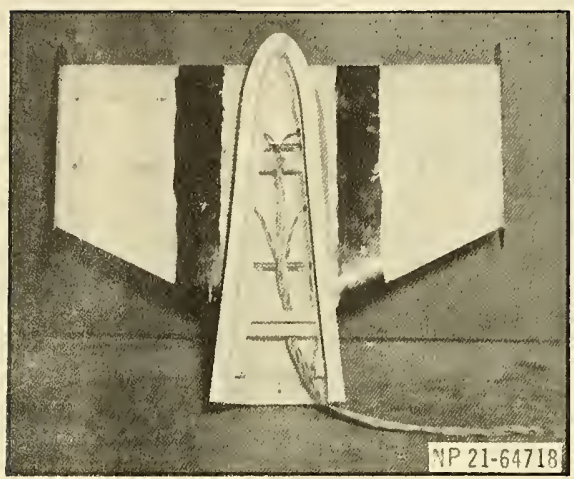

Fin No. 1

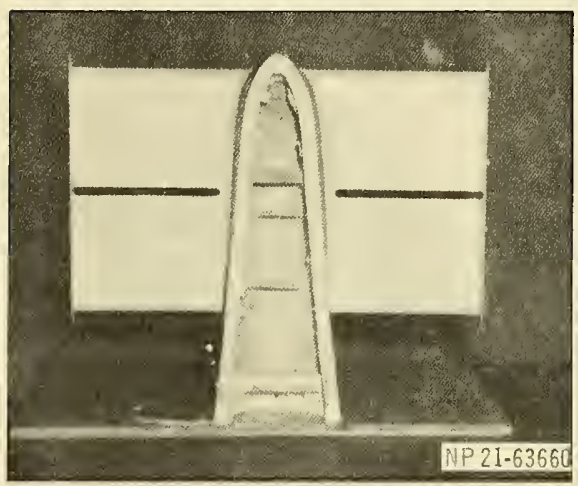

Fin No. 2

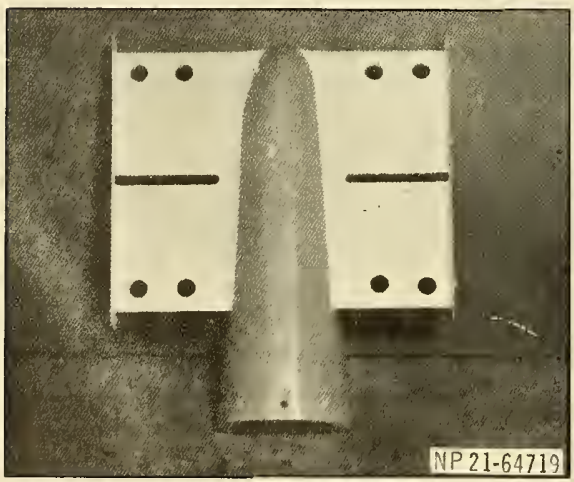

Fin No. $2 h$

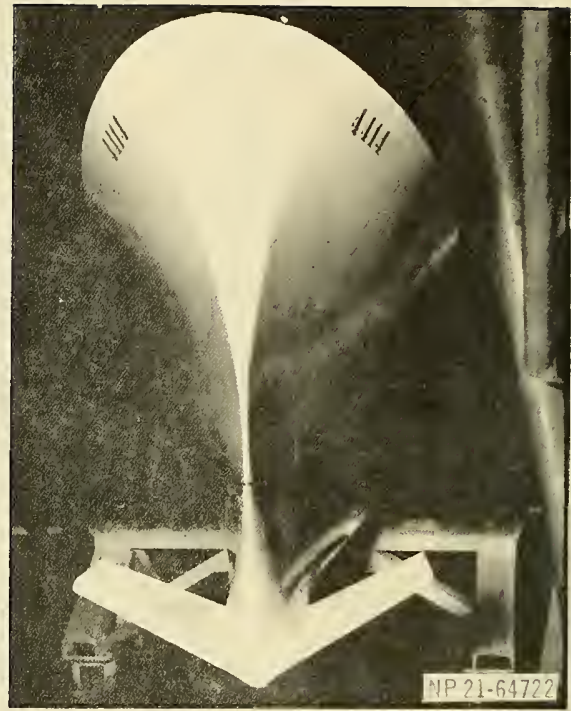

Fin No. 3

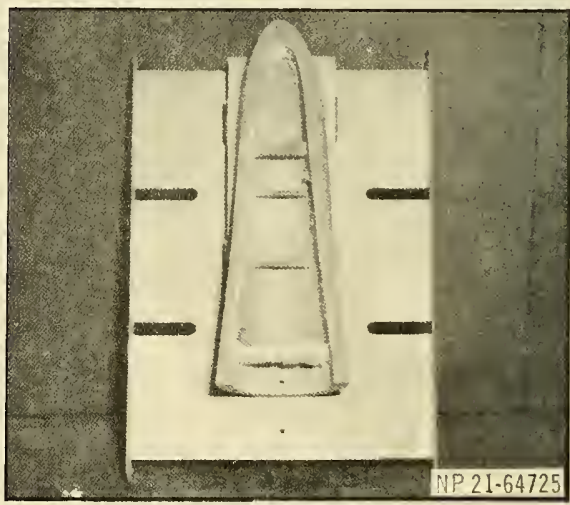

Fin No. 4

Figure 5 - Antipitching Fins 


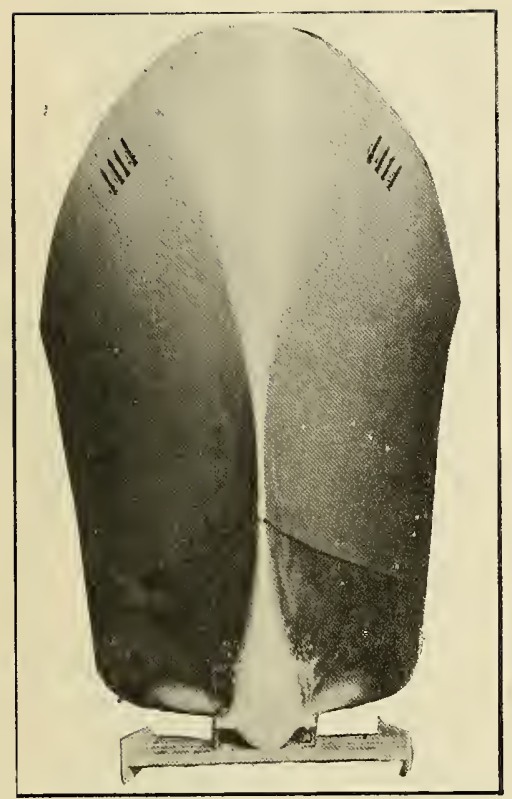

"Triplet" Configuration

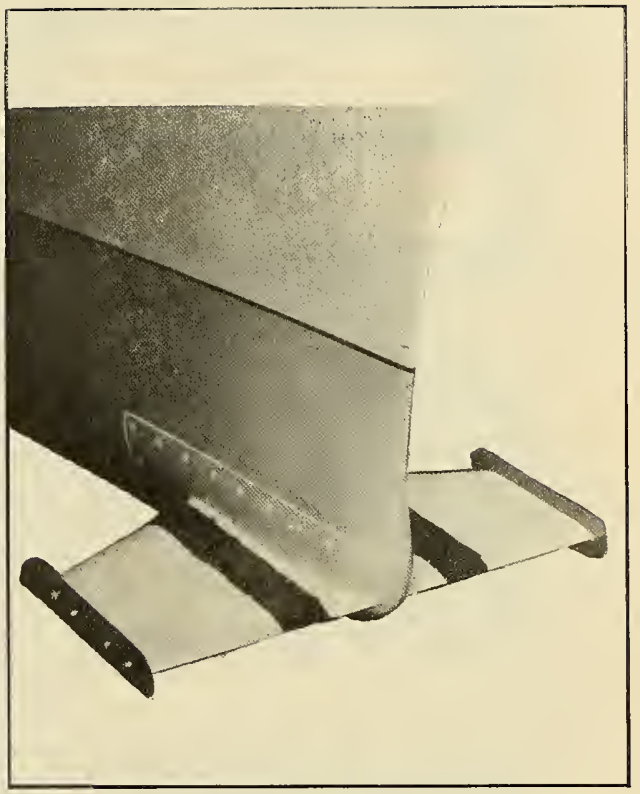

Fin 1 (Principal Fin)

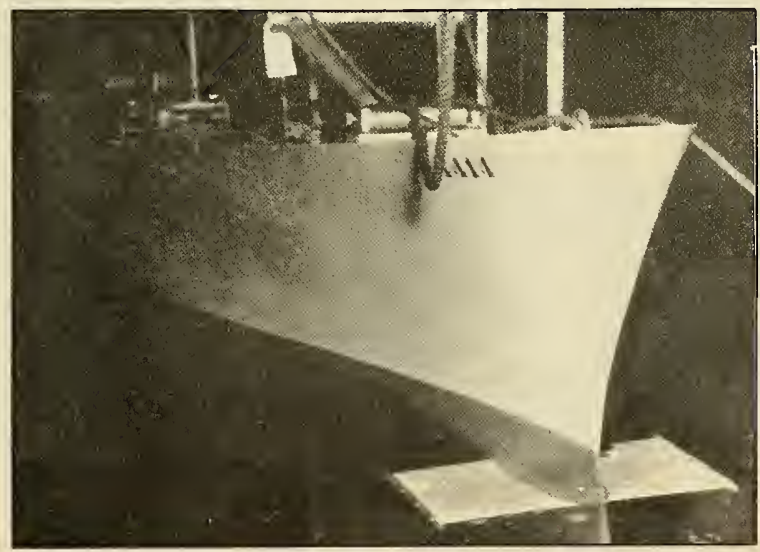

"Twin" Configuration

Figure 6 - Three Model Installations of Antipitching Fins 
middle of the overall chord. Such flow relief was considered desirable in view of previous experience with antipitching fins at the Model Basin. ${ }^{1}$ Tip fences, similar to those of Fin No. 1, were also fitted. The plan area of the configuration outboard of the hull was again 2.2 percent of the load-waterplane area.

Fins No. $2 s$ and No. $2 h$ were obtained by modifying the plan of Fin No. 2. Fin No. $2 s$ was obtained first by reducing the full-scale span by 10 feet so as to make the tip to tip distance 28 feet, and the plan area was reduced to 1.4 percent of the load-waterplane area. Fin No. $2 h$ was obtained next by drilling holes corresponding to a full-scale diameter of 18 inches, 2 feet from the leading and trailing edges of Fin No. $2 s$, port and starboard. The purpose of testing these modifications was to investigate the effects of a further reduction of plan area, ${ }^{1}$ and the possibility of decreasing the adverse effects of fin vorticity experienced when the fins approach the surface. Such vorticity effects are considered structurally undesirable. Tip fences were retained in both of the above modifications.

Fin No. 3 Dihedral Configuration. This configuration retained the plan geometry of Fin No. 1, and was obtained by rotation about the root chord. The dihedral angle was 30 degrees. The purpose of this configuration was to investigate the effect on slamming of the wedge entrance so formed. It was for this purpose that the dihedral angle used was as large as 30 degrees. This configuration was not fitted with tip fences.

Fin No. 4 Triple Configuration. This configuration was rectangular in plan, and consisted of three fins in series each corresponding to 28 feet by 12 feet. The plan area outboard of the 3 -foot waterline was 2.3 percent of the load-waterplane area. In this case, however, the upper surface of the fins was attached to the underside of the keel forward, with more support provided by two thin struts, port and starboard. The middle fin had a clearance corresponding to 1 foot from either of the forward or after fins. The purpose of testing this configuration was to investigate the effects of deeper fin submergence on fin vorticity. Tip fences were installed in this configuration.

A modification, Fin No. $4 h$, was obtained by drilling holes of a full-scale diameter of 1 foot on both sides of each of the three fins.

\section{INSTRUMENTATION}

Direct data obtained from the model tests included wave elevation, strain, and pitch and heave amplitudes. All data taken were recorded on an 8-channel oscillograph recorder.

\footnotetext{
${ }^{1}$ References are listed on page 29.
} 


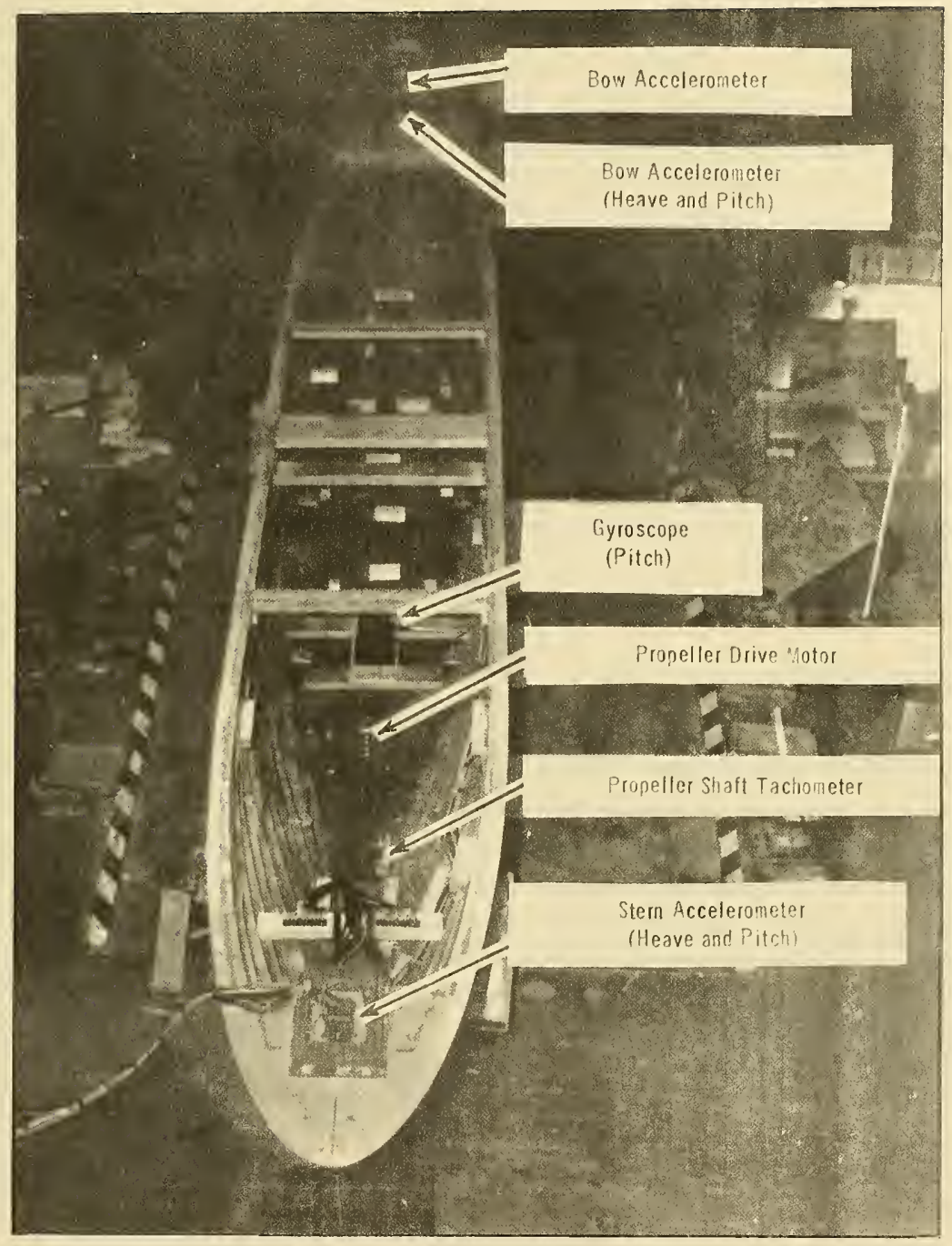

Figure 7 - Installation of Instruments

Not shown in this photograph is a heave measuring potentiometer fitted at the towing pantograph, and a surge potentiometer at the guide-line pulley. 
Wave data were obtained with a capacitance-type, partially submerged, wire probe. Pitch data were obtained with a gyroscope located amidships. Heave data were obtained with a linear displacement potentiometer installed on the moving arms of a special pantograph at the LCG. Pitch and heave data were also computed from direct measurements of the sum and the difference of the instananeous accelerations recorded by two vertical accelerometers located at equal distances fore and aft of the LCG. Motion data were also obtained with a $35 \mathrm{~mm}$ movie camera.

The principal fin configuration, Fin No. 1, was equipped with two bending flexures on each side, to obtain data on strain due to bending moments experienced by the fin in waves. Each flexure had a complete four-active-arm bending bridge. The flexures were calibrated prior to testing.

In addition to the instrumentation described above, the model was equipped with an electric motor driving the propeller, a propeller shaft tachometer, an independent vertical accelerometer located at the bow, and an angular displacement type potentiometer for surge data.

Figure 7 shows the layout of the instruments.

\section{TEST PROGRAII}

The tests were conducted at a model displacement of 2699 pounds, corresponding to 17,505 tons for the ship. The draft was 12.4 inches even keel, corresponding to 25 feet full scale. The tests originally called for a displacement corresponding to 15,870 tons at a mean draft of 23 feet, with a trim of 4 feet by the stern. Tests at this load condition, however were discontinued because the model without the fins exhibited frequent forebody emergence, occasionally extending to more than one-half the ship's length. The design displacement of the Mariner is 21,093 tons at a draft of 29 feet $101 / 16$ inches even keel.

Tables 2 and 3 give the speed and wave size schedules, respectively, of the tests.

TABLE 2

Schedule of Tests - Speed

\begin{tabular}{|c|c|c|}
\hline \multicolumn{2}{|c|}{ Speed, knots } & \multirow{2}{*}{$F_{n}$} \\
\cline { 1 - 2 } Model & Ship & \\
\hline 0 & 0 & 0 \\
1 & 4.82 & 0.065 \\
2 & 9.64 & 0.129 \\
3 & 14.46 & 0.191 \\
4 & 19.28 & 0.255 \\
\hline
\end{tabular}




\section{TABLE \&}

Schedule of Tests - Wrve Size

\begin{tabular}{|c|c|c|c|c|c|}
\hline \multicolumn{4}{|c|}{ Yaves } & \multirow{3}{*}{$\lambda / L$} & \multirow{3}{*}{$\lambda / h$} \\
\hline \multicolumn{2}{|c|}{ Model } & \multicolumn{2}{|c|}{ Ship } & & \\
\hline Length, ft & Height, in. & Length, ft & Height, $\mathrm{ft}$ & & \\
\hline 15 & $3,4.5,6$ & 360 & $6,9,12$ & 0.703 & $60,40,30$ \\
\hline 20 & $4,6,8$ & 480 & $8,12,16$ & 0.937 & $60,40,30$ \\
\hline 25 & $5,7.5,10$ & 600 & $10,15,20$ & 1.172 & $60,40,30$ \\
\hline 30 & $6,9,12$ & 720 & $12,18,24$ & 1.406 & $60,40,30$ \\
\hline
\end{tabular}

The radius of gyration was established experimentally at 25 percent LWL. The natural pitch period of the model for the load condition corresponding to 17,505 tons full scale was 1.44 seconds. The addition of Fin No. 1 increased the natural pitch period to 1.59 seconds. It was not possible to obtain the natural heave period because of the limitations imposed by the size of the model and the width of the test basin.

\section{TEST RESULTS}

The experimental results are presented in Figures 8 through 15. The results include the experimental heave and pitch amplitudes and phase angies, the computed location of the point of minimum vertical motion, the vertical motion and acceleration of any point along the length of the ship, and the computed values of the bending moments experienced by Fin No. 1 in waves. All dimensional results are presented in full scale and are summarized in the conventional dimensionless form. The pitch reduction effects of the various fin configurations tested are also presented.

Because of the frequent propeller emergence experienced during the tests with and without fins, propeller rpm and surge data were erratic. The presentation of these data has, therefore, been omitted.

\section{PITCH (Figure 8)}

Pitch amplitudes shown are experimental. Linearity of pitch amplitude with wave height at constant speed and wave length was found to hold within the wave-height range of the tests (the highest waves were $1 / 30$ of their length). The data are presented in graphical form, showing the amplitude of pitch per unit of wave height measured from trough to crest. Pitch amplitudes for wave lengths not included in the direct presentation can be obtained by interpolation. It will, however, be necessary to perform the interpolation graphically, as linearity assumptions involving the wave length are not valid. 


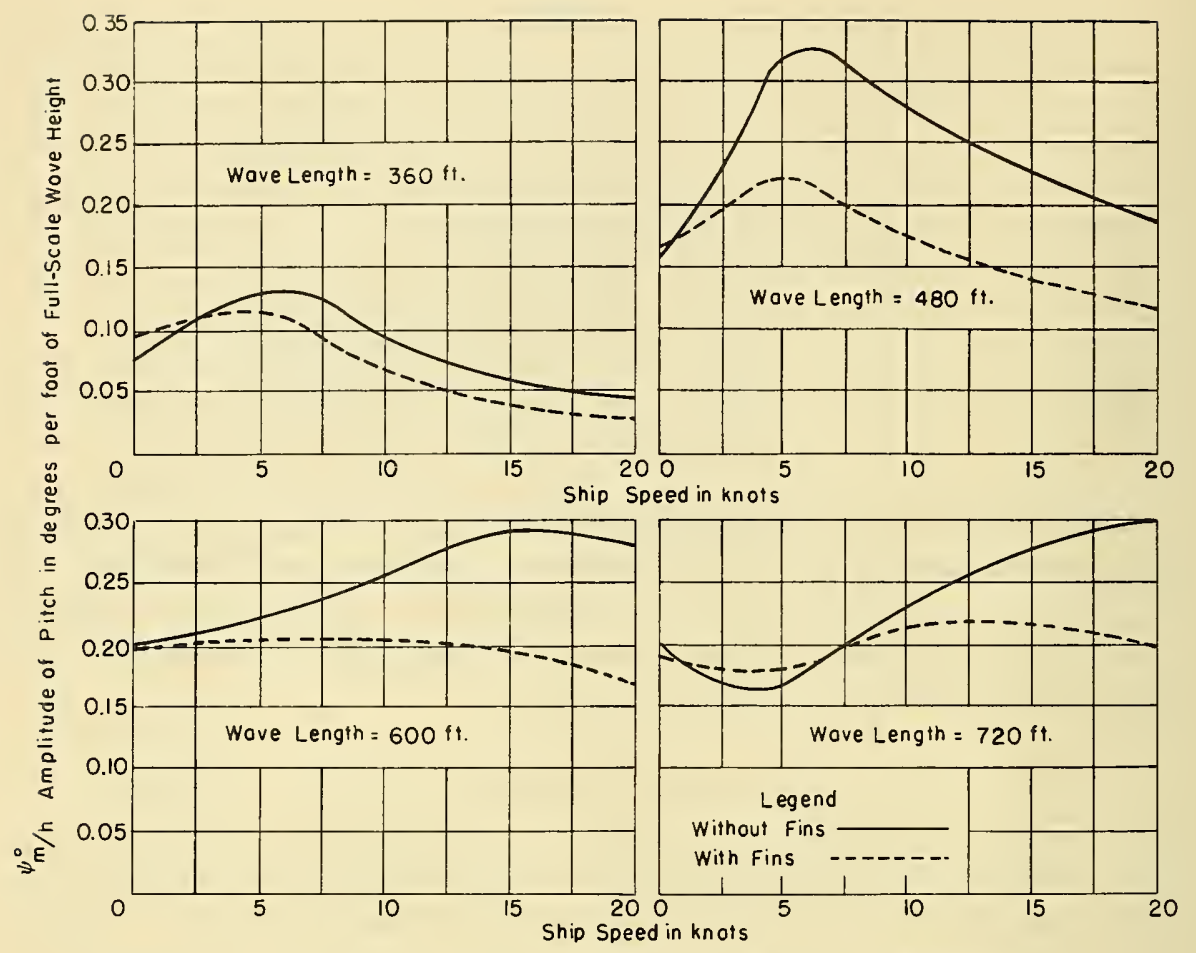

Figure 8 - Experimental Pitch Amplitudes As a Function of Wave Height

\section{HEAVE (Figure 9)}

Heave amplitudes shown are experimental. Linearity of heave with wave height at constant speed and wave length was found to hold within the wave-height range of the tests, as in the case of pitch. The data are presented in graphical form, showing the amplitude of heave per unit of wave height measured from trough to crest. Heave amplitudes for wave lengths not included in the direct presentation can be obtained by graphical interpolation.

\section{PHASE LAG OF HEAVE REFERRED TO PITCH (Figure 10)}

Values of phase lag of heave referred to pitch were determined directly from the experimental data. The variations in phase lag with wave height at constant speed and wave length remained within the estimated accuracy of record interpretation. It was then assumed that for this model the wave height had no effect on the phase relation between heave and pitch. Phase values for wave lengths not included in the direct presentation can be obtained by graphical interpolation. 

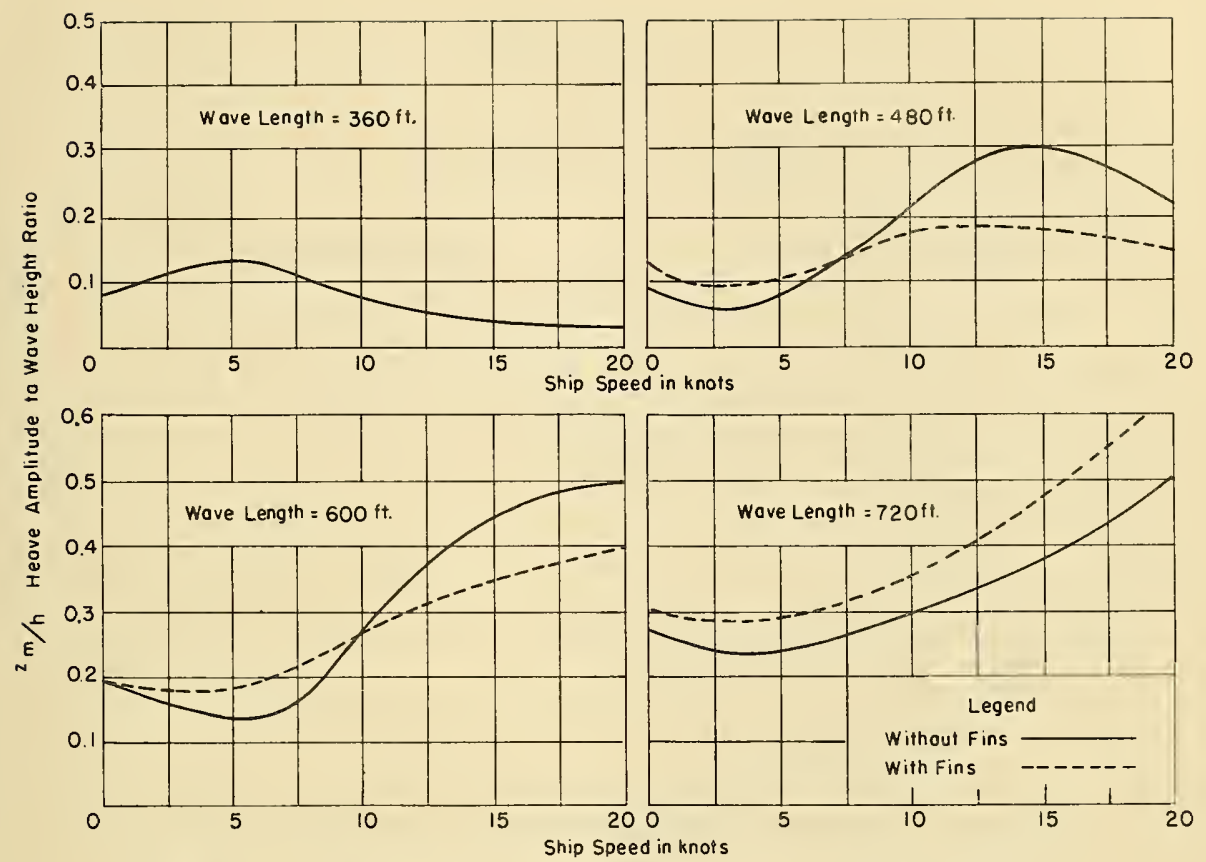

Figure 9 - Experimental Heave Amplitude As a Function of Wave Height

\section{POINT OF MINIMUM VERTICAL MOTION (Figure 11 )}

The location of the point of minimum vertical motion, (apparent pitching axis), ${ }^{2}$ was computed from experimental values of heave, pitch, and their phase relationship. In such computations sinusoidal ship motion was assumed. Sinusoidal motion was verified to the extent that the pitch and heave amplitudes obtained directly from the gyroscope and potentiometer were within 5 percent of the values computed from the sum and differences of the instantaneous accelerations of two equi-distant points fore and aft of the $\mathrm{LCG}$. As the pitch and heave amplitudes are linear with wave height, the point of minimum motion is independent of wave steepness within the range of the tests.

\section{VERTICAL MOTION AND ACCELERATION (Figures 12a through 13d)}

The amplitude of the vertical motion and the acceleration of any point aiong the length of the ship were computed from experimental values of heave, pitch, and their phase relationship. Sinusoidal ship motion was assumed. The amplitude of the vertical motion or acceleration of any given point along the length of the ship is linear with wave height at constant speed and wave length. 


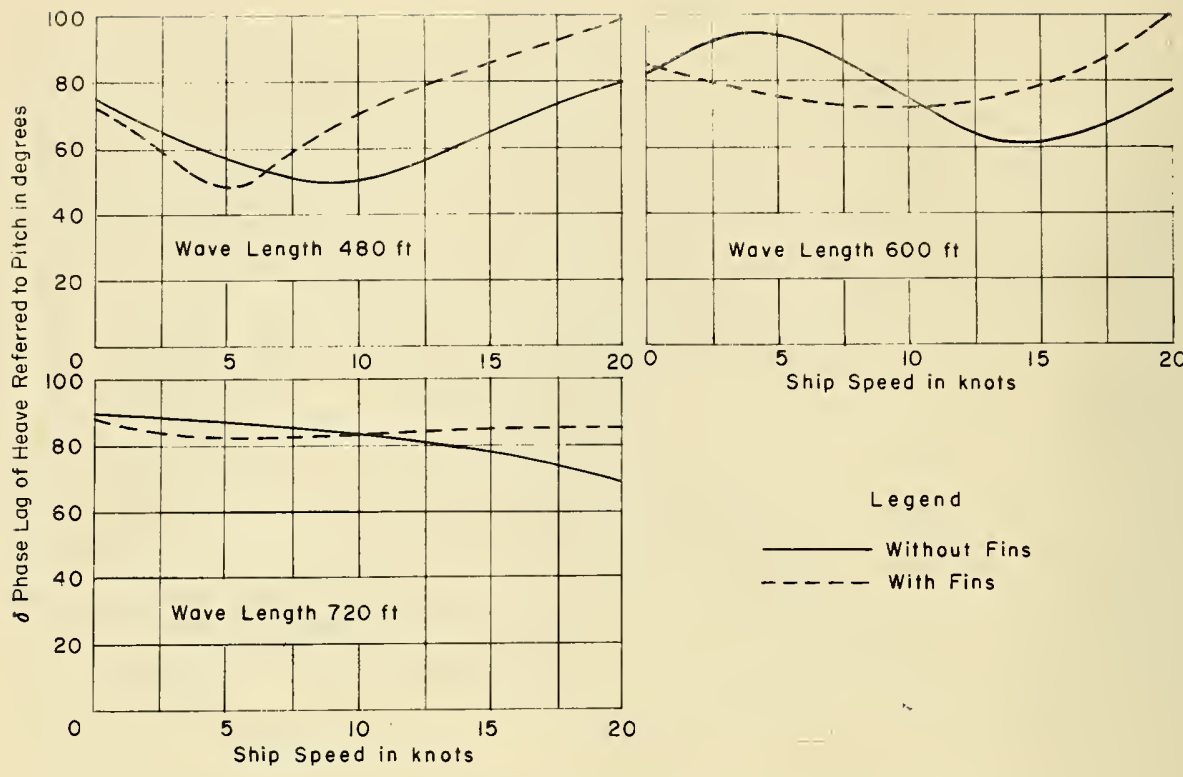

Figure $10-$ Experimental Phase Relationship Between Heave and Pitch

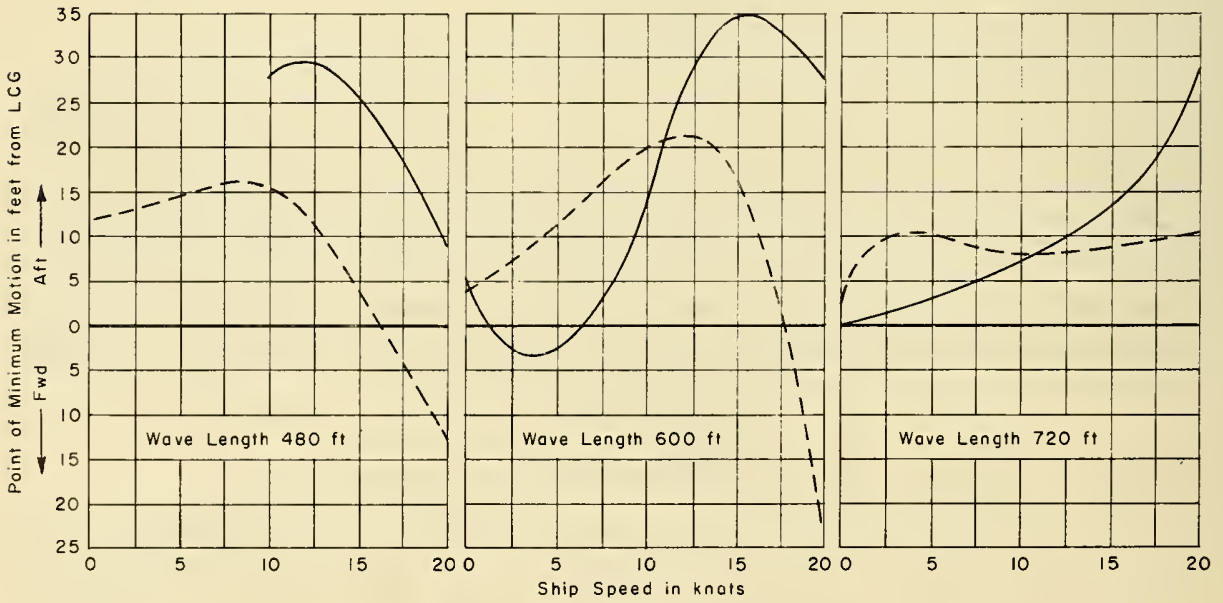

Figure 11 - Computed Location of Point of Minimum Vertical Motion 
Figure 12-Compatent mpitude of Vertical hotion Along Length of Ship

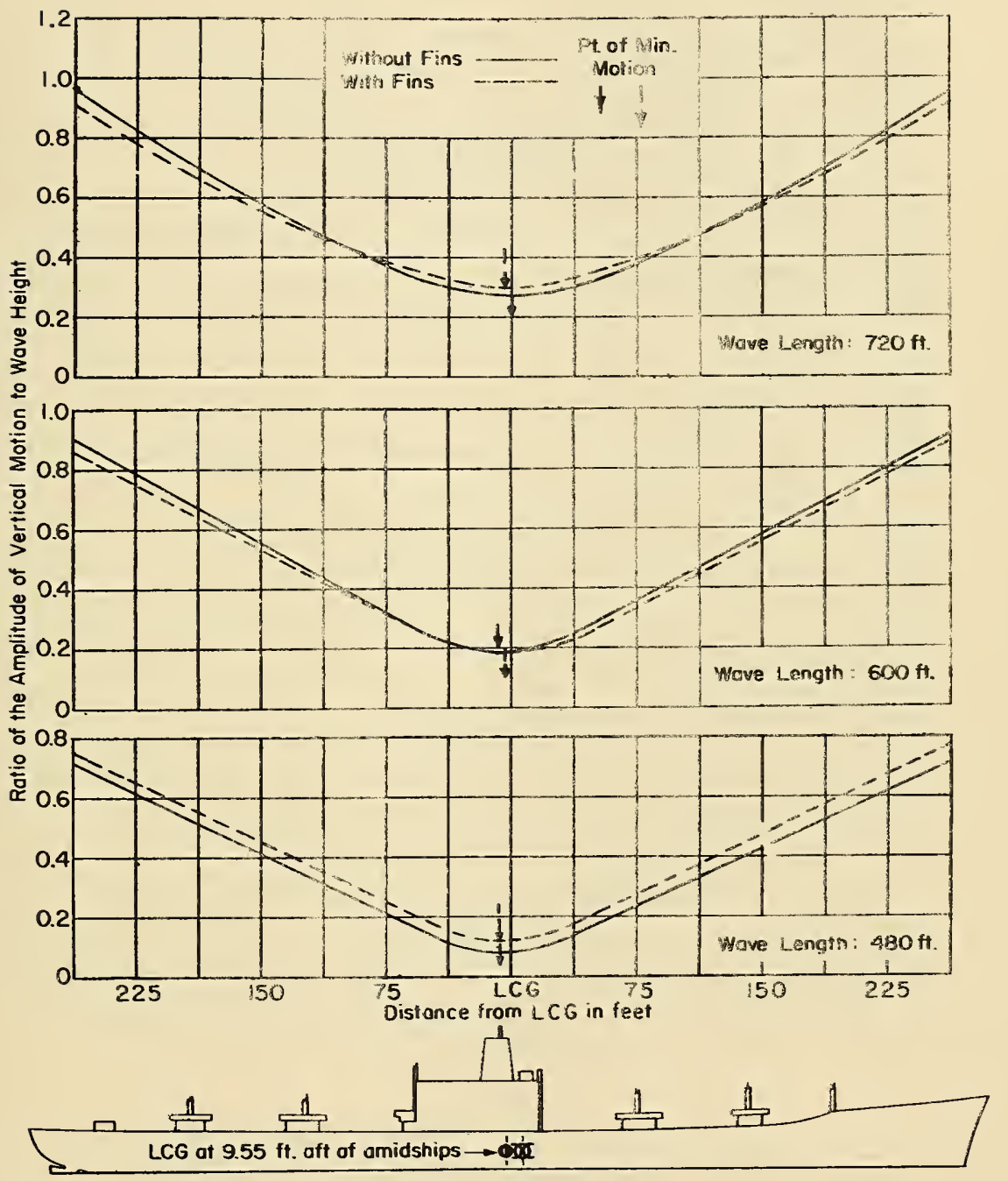

Figure 12a- "Zero" Speed 


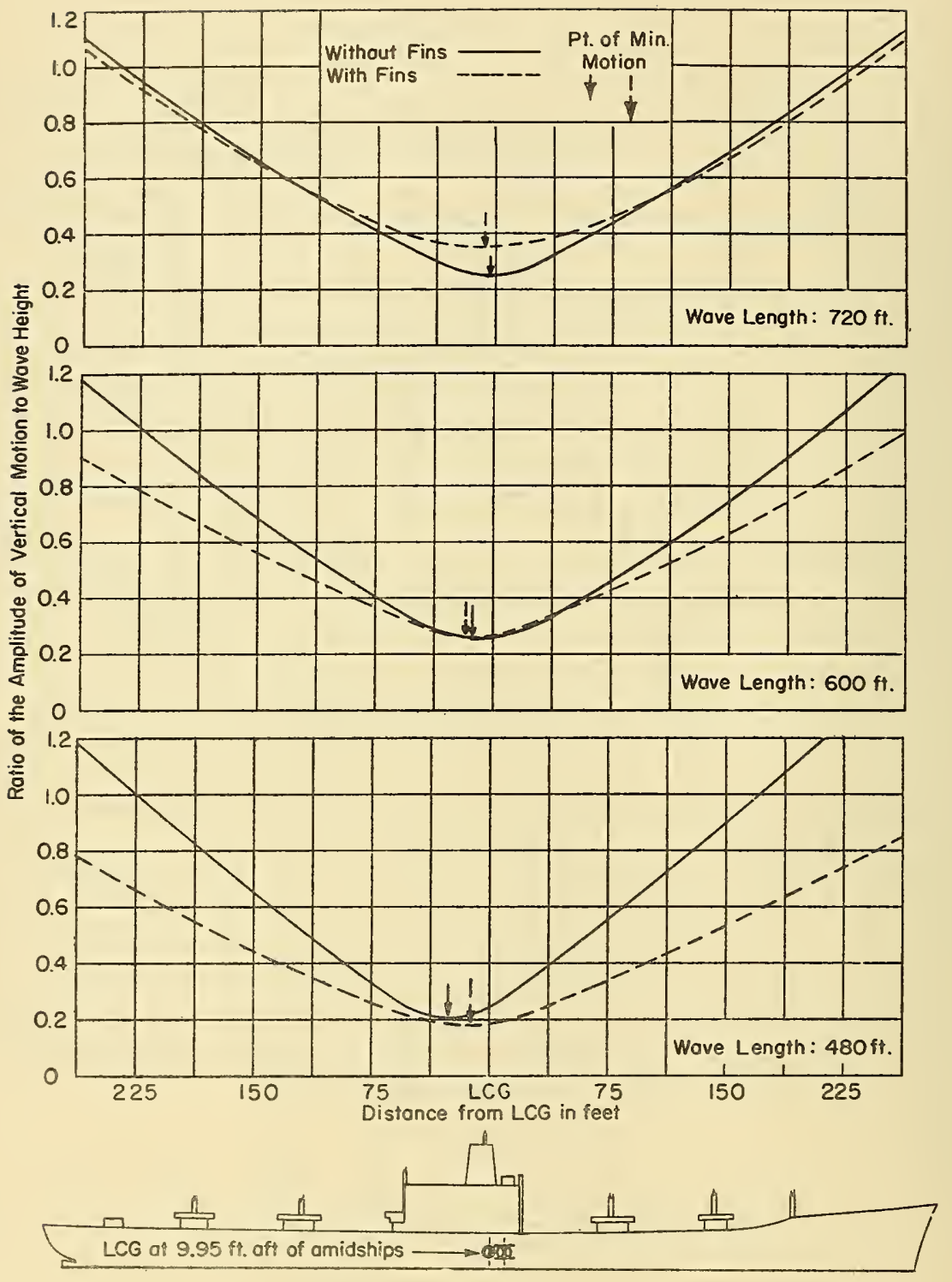

Figure $12 b-10$ Knots 


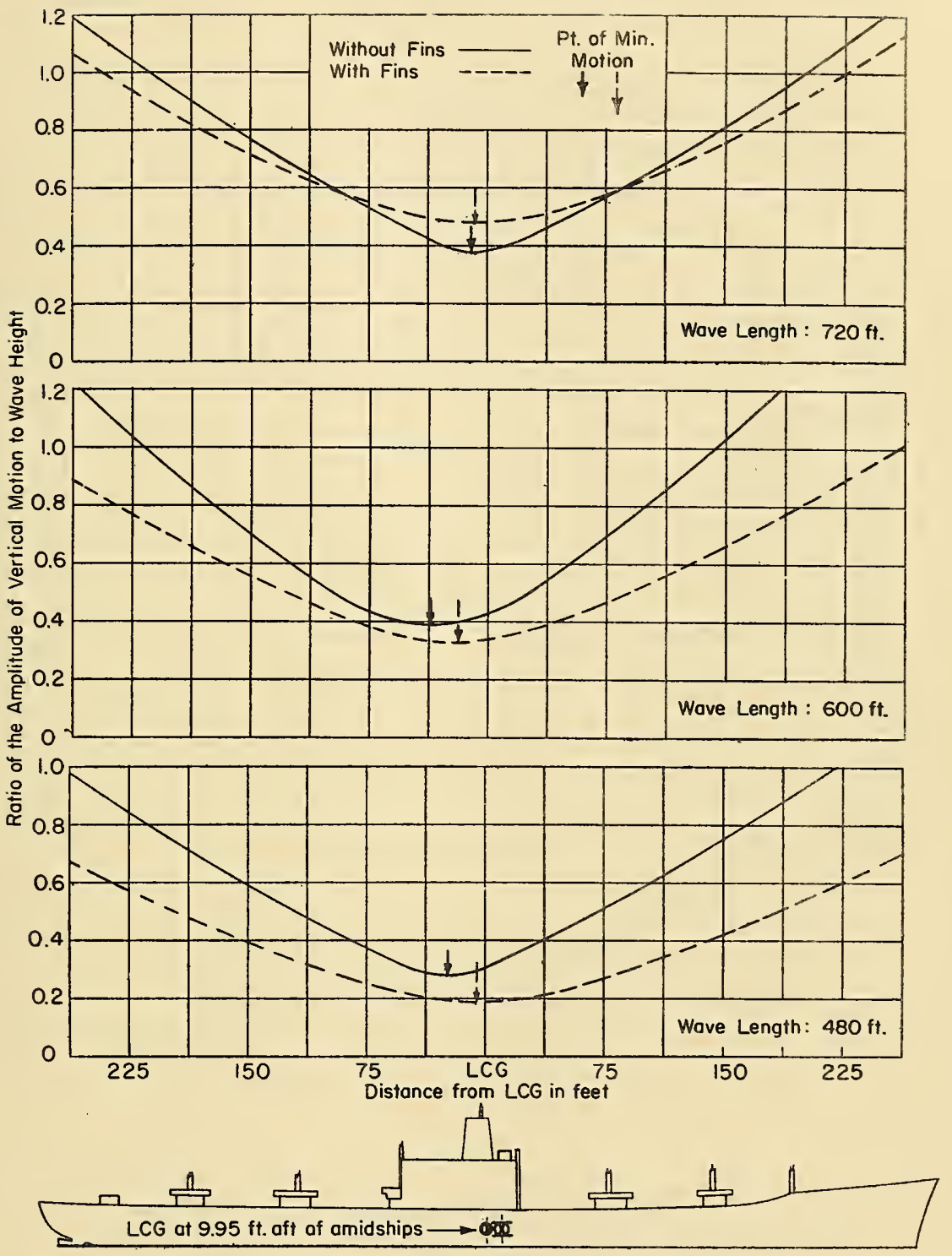

Figure $12 c-15$ Knots 


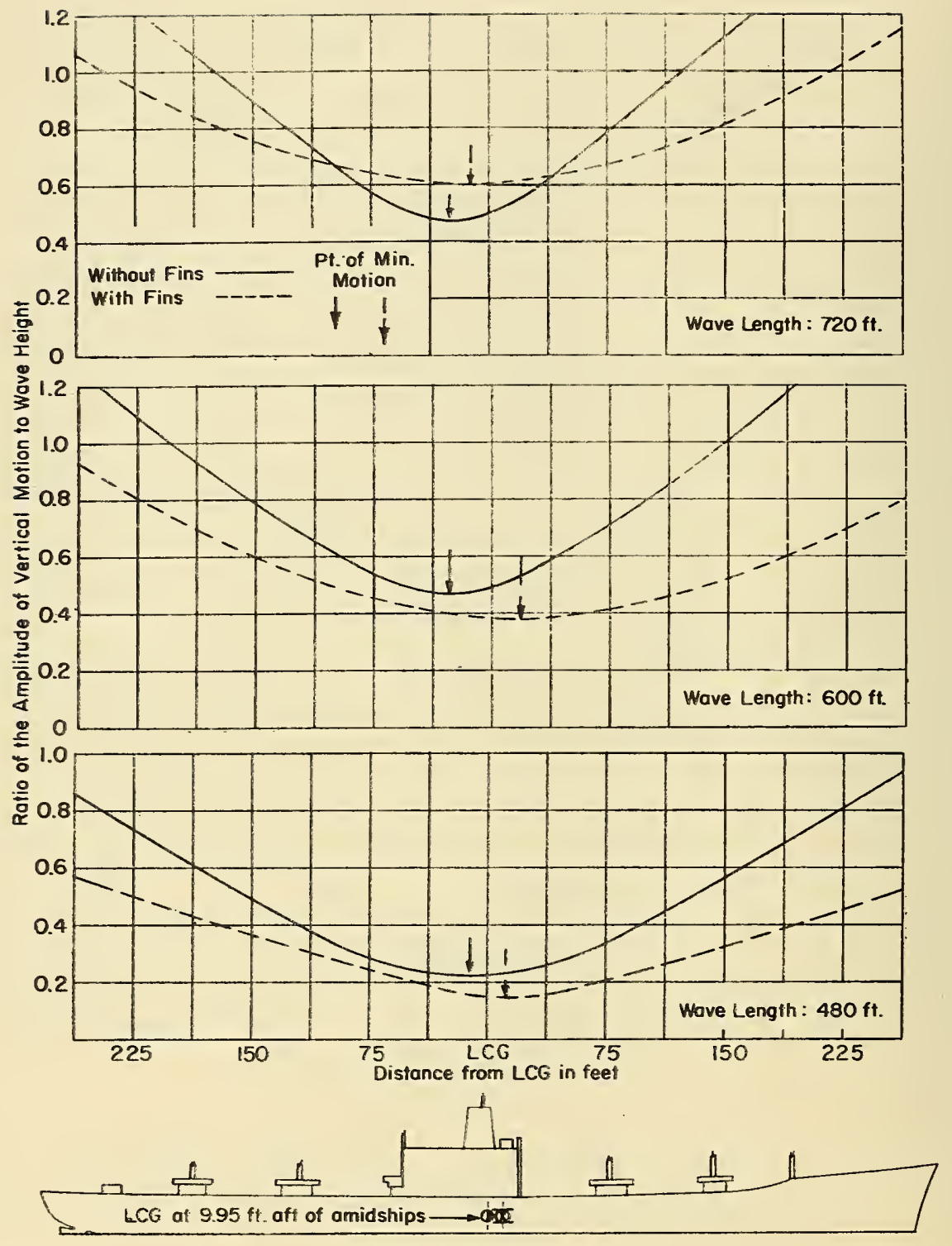

Figure $12 d-20$ Knots 
Figure 13 - Compurend Ant itude of Vertical Acceleraton A Aong Length of Ship

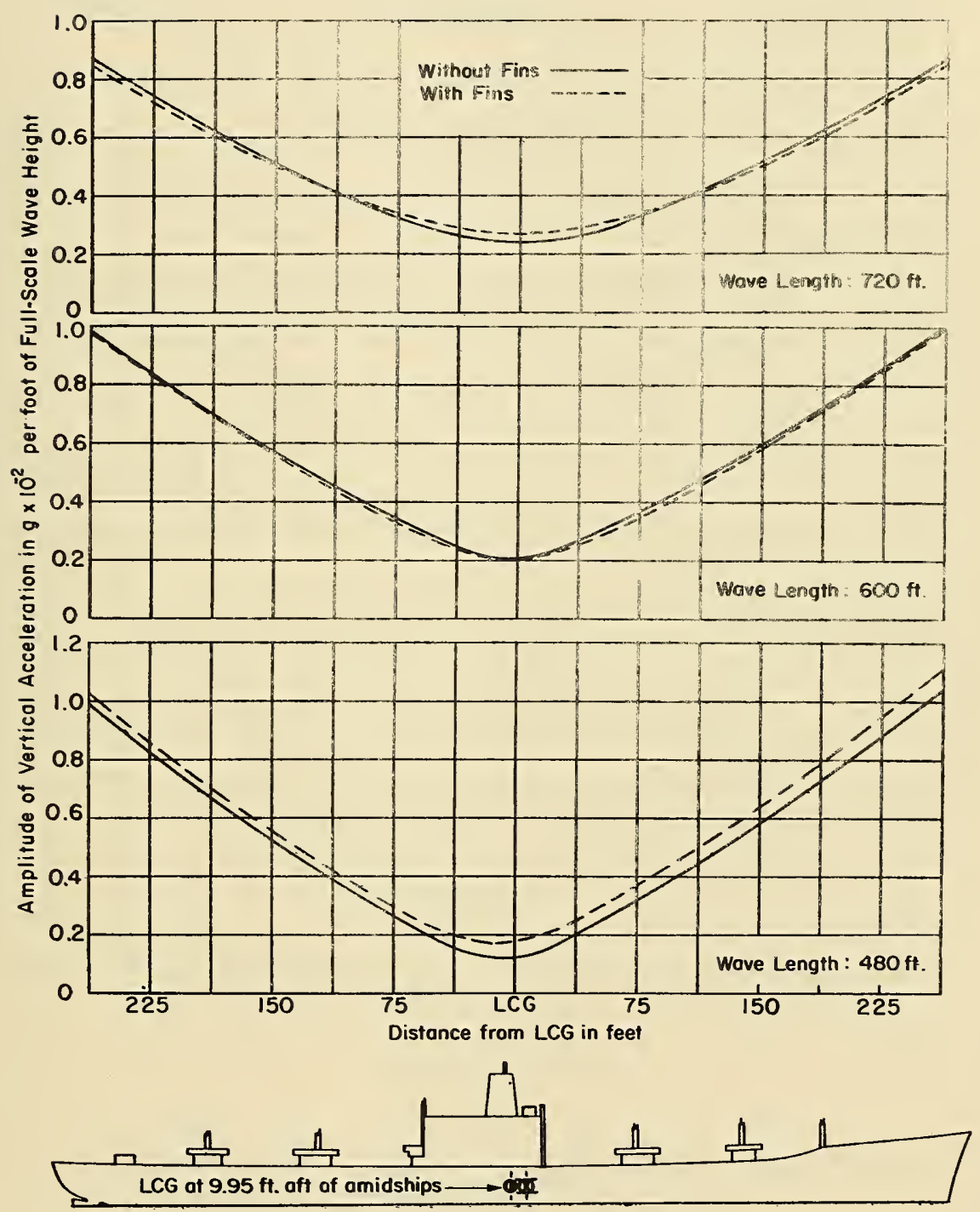

Figure 13a - "Zero" Speed 


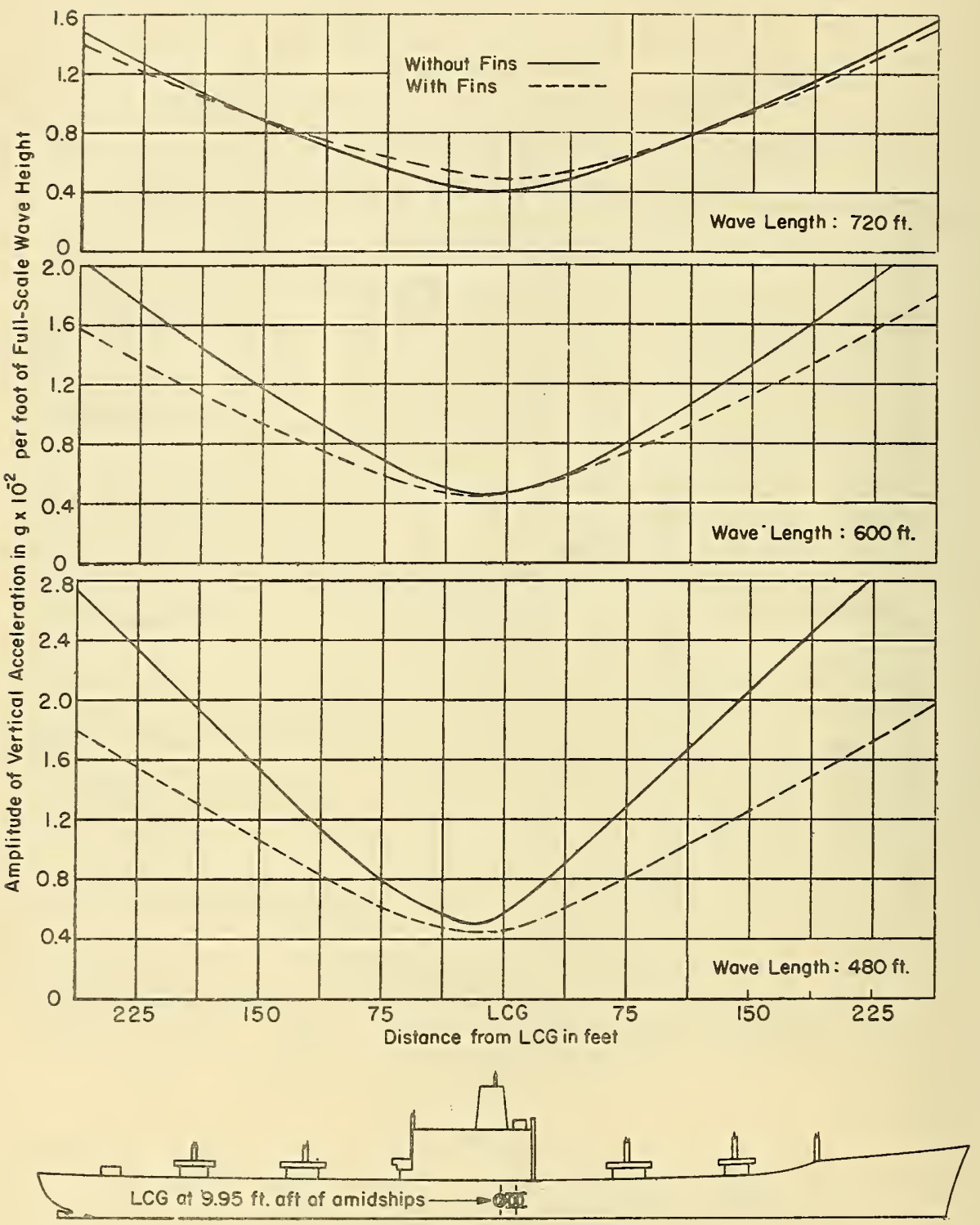

Figure $13 \mathrm{~b}-10 \mathrm{Knots}$ 


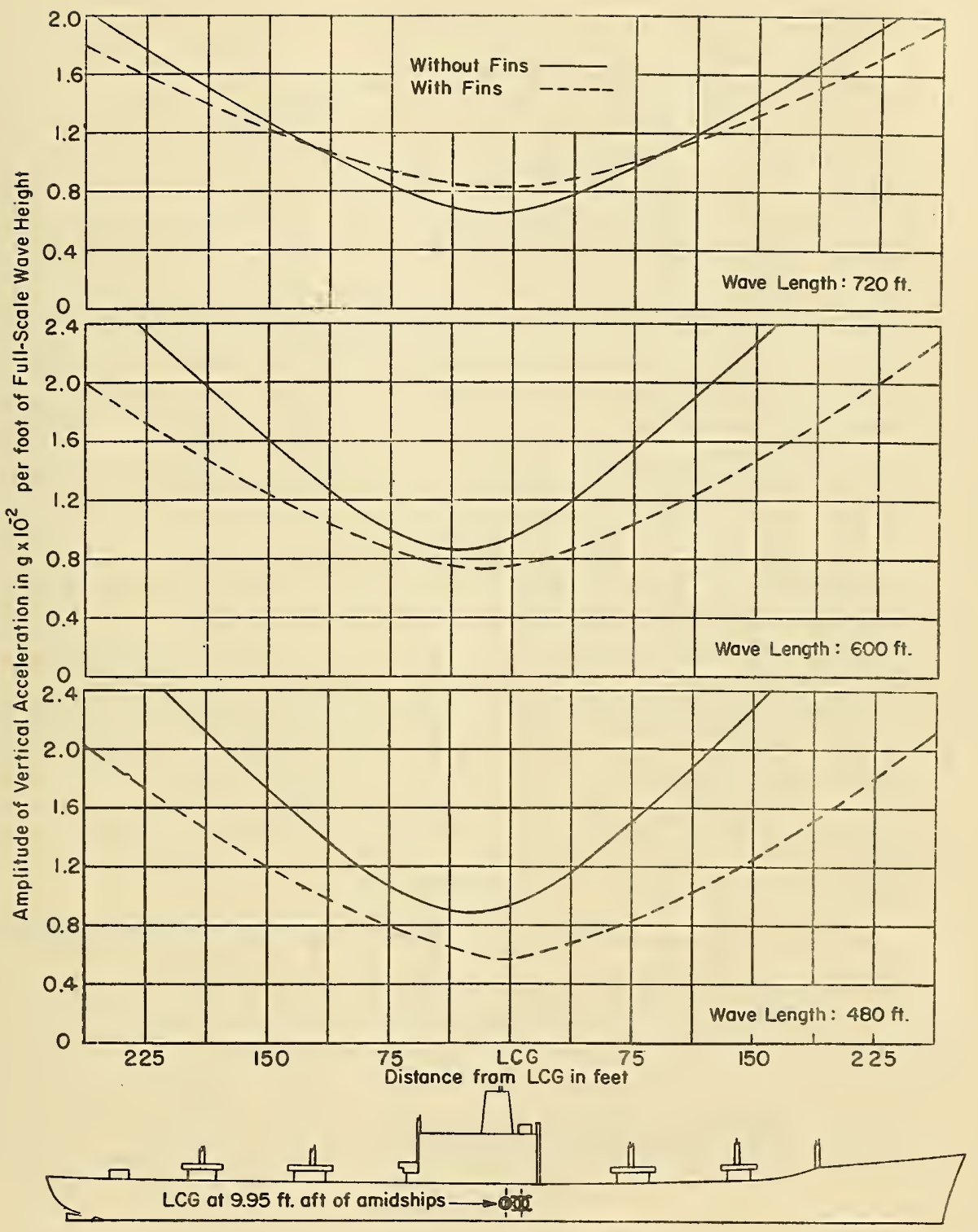

Figure $13 c-15$ Knots 


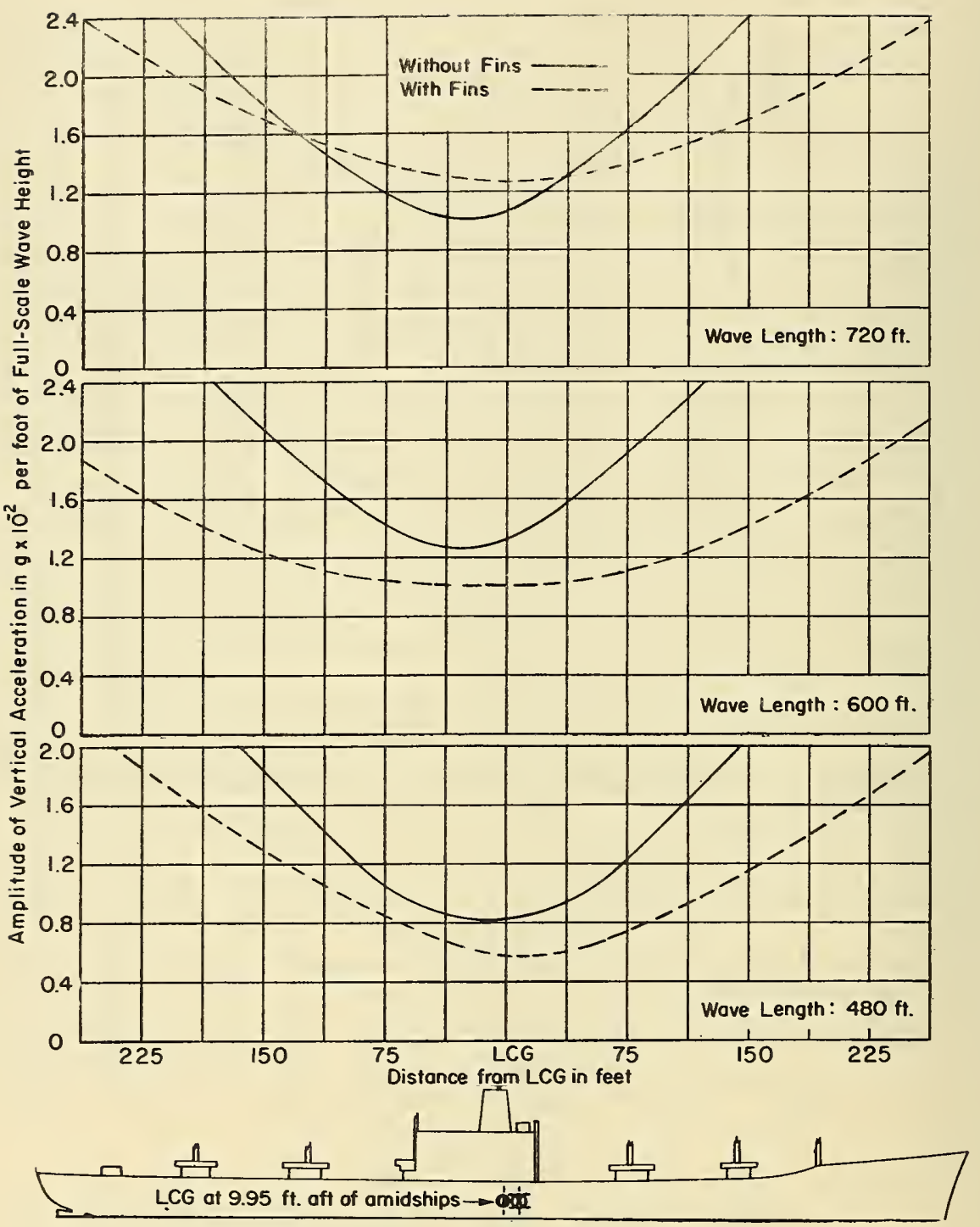

Figure 13d - 20 Knots 
TABLE 4

Comparison of Pitch Amplitudes

Fin symbols correspond to those listed in the Introduction of this report.

\begin{tabular}{|c|c|c|c|c|c|c|c|c|c|}
\hline \multirow{2}{*}{$\begin{array}{c}\text { Have } \\
\text { Length } \\
\text { feet }\end{array}$} & \multirow{2}{*}{$\begin{array}{l}\text { Speed } \\
\text { knots }\end{array}$} & \multicolumn{8}{|c|}{$\begin{array}{c}\text { Amplitude of Pitch } \\
\text { degrees per foot of wave height }\end{array}$} \\
\hline & & $\begin{array}{l}\text { No } \\
\text { Fin }\end{array}$ & $\begin{array}{c}\text { Fin } \\
1\end{array}$ & $\begin{array}{c}\text { Fin } \\
2\end{array}$ & $\begin{array}{l}\text { Fin } \\
2 s\end{array}$ & $\begin{array}{l}\text { Fin } \\
2 h\end{array}$ & $\begin{array}{c}\text { Fin } \\
3\end{array}$ & $\begin{array}{c}\text { Fin } \\
4\end{array}$ & $\begin{array}{r}\text { Fin } \\
4 h\end{array}$ \\
\hline \multirow{5}{*}{480} & 0 & 0.155 & 0.165 & 0.16 & 0.165 & * & 0.145 & 0.18 & 0.165 \\
\hline & 4.82 & 0.32 & 0.22 & 0.205 & 0.25 & * & 0.205 & 0.22 & * \\
\hline & 9.64 & 0.28 & 0.18 & 0.175 & 0.18 & * & 0.185 & 0.185 & 0.18 \\
\hline & 14.46 & 0.23 & 0.145 & 0.145 & 0.165 & * & 0.155 & 0.165 & 0.165 \\
\hline & 19.28 & 0.19 & 0.12 & 0.12 & 0.125 & * & 0.115 & 0.12 & * \\
\hline \multirow{5}{*}{600} & 0 & 0.20 & 0.195 & 0.195 & 0.195 & 0.205 & 0.205 & 0.20 & 0.20 \\
\hline & 4.82 & 0.22 & 0.20 & 0.195 & 0.22 & 0.21 & 0.215 & 0.215 & 0.21 \\
\hline & 9.64 & 0.255 & 0.205 & 0.20 & 0.225 & 0.215 & 0.235 & 0.225 & 0.22 \\
\hline & 14.46 & 0.29 & 0.195 & 0.19 & 0.235 & 0.24 & 0.23 & 0.22 & 0.225 \\
\hline & 19.28 & 0.28 & 0.17 & 0.165 & 0.20 & 0.21 & 0.195 & 0.20 & 0.205 \\
\hline \multirow{5}{*}{720} & 0 & 0.20 & 0.19 & 0.18 & * & * & 0.165 & 0.19 & * \\
\hline & 4.82 & 0.165 & 0.18 & 0.165 & * & * & 0.155 & 0.165 & * \\
\hline & 9.64 & 0.23 & 0.21 & 0.205 & * & * & 0.19 & 0.215 & $*$ \\
\hline & 14.46 & 0.225 & 0.21 & 0.205 & * & * & 0.195 & 0.225 & * \\
\hline & 19.28 & 0.30 & 0.20 & 0.19 & * & * & 0.195 & 0.21 & * \\
\hline
\end{tabular}

\section{AVERAGE BENDING MOMENT OF FIN NO. 1 (Figure 14)}

The average bending moment experienced by the fin in waves was determined from experimental strain measurements. The moments shown in Figure 14 are averages of the "up" and "down" values. The moments have also been averaged along the chord. The experimental strain records indicate that the bending moment of the forward flexure was higher than that of the after flexure at ship speeds above approximately 10 knots. This is attributed to the arrangement of the bending flexures, the tapered plan of the fin, and the type of distributed loading.

\section{COMPARATIVE PITCH REDUCTION OF FINS TESTED (Figure 15)}

The amplitudes of the pitch with the various fin configurations tested are shown in Table 4 above. These are compared graphically in Figure 15. A more extensive discussion 

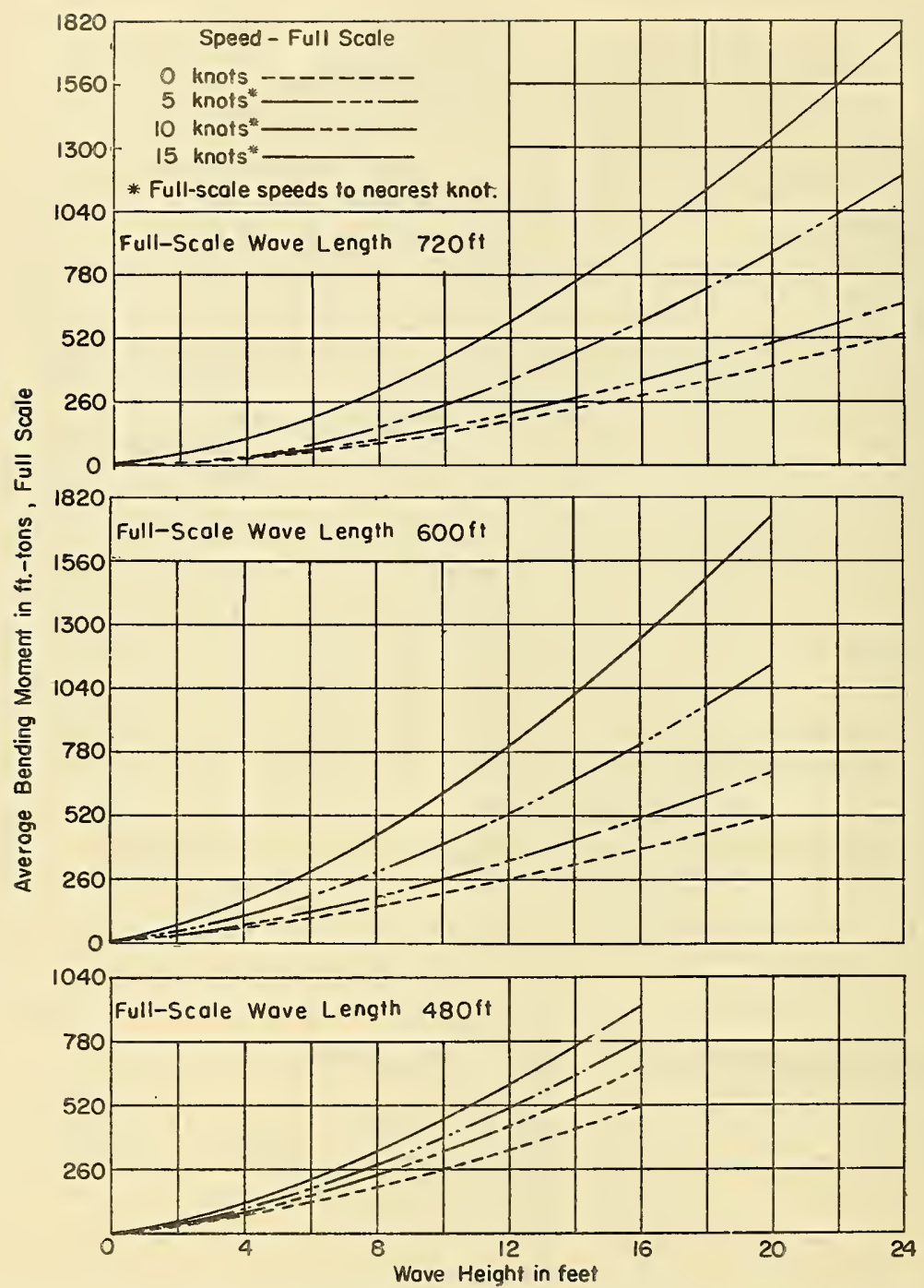

Figure 14 - Experimental Average Bending Moments Experienced in Waves by Fin No. 1 7 Feet off Centerline 


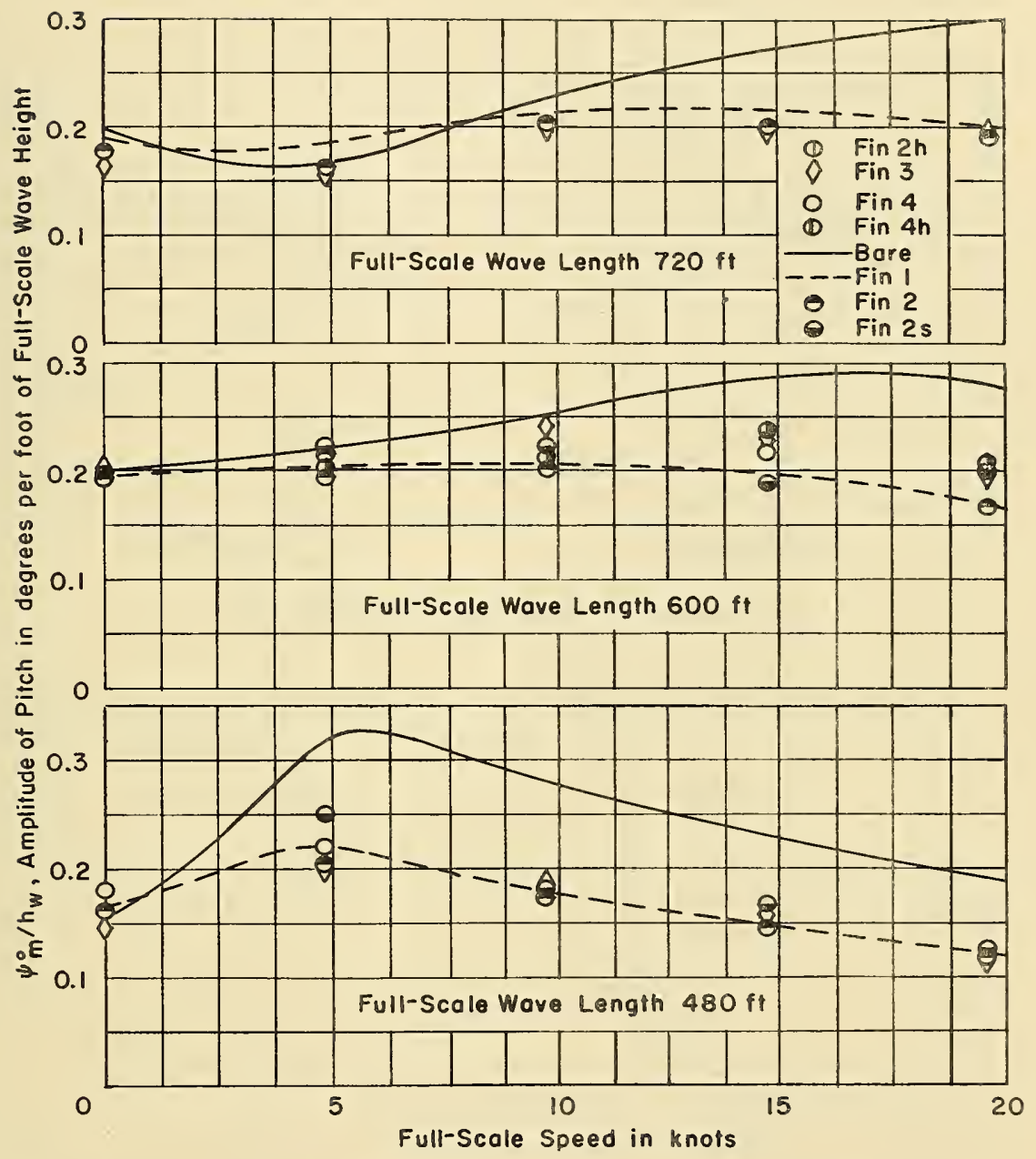

Figure 15 - Comparative Performance of Various Fin Configurations Tested 

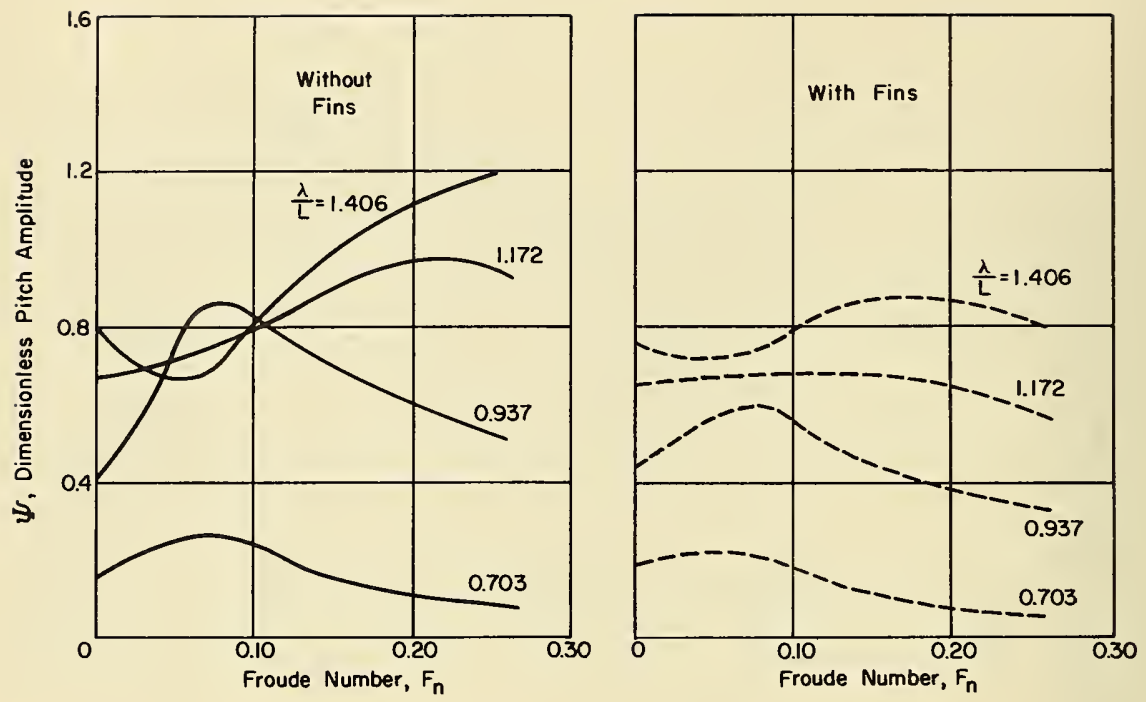

Figure 16 - Dimensionless Pitch Amplitudes
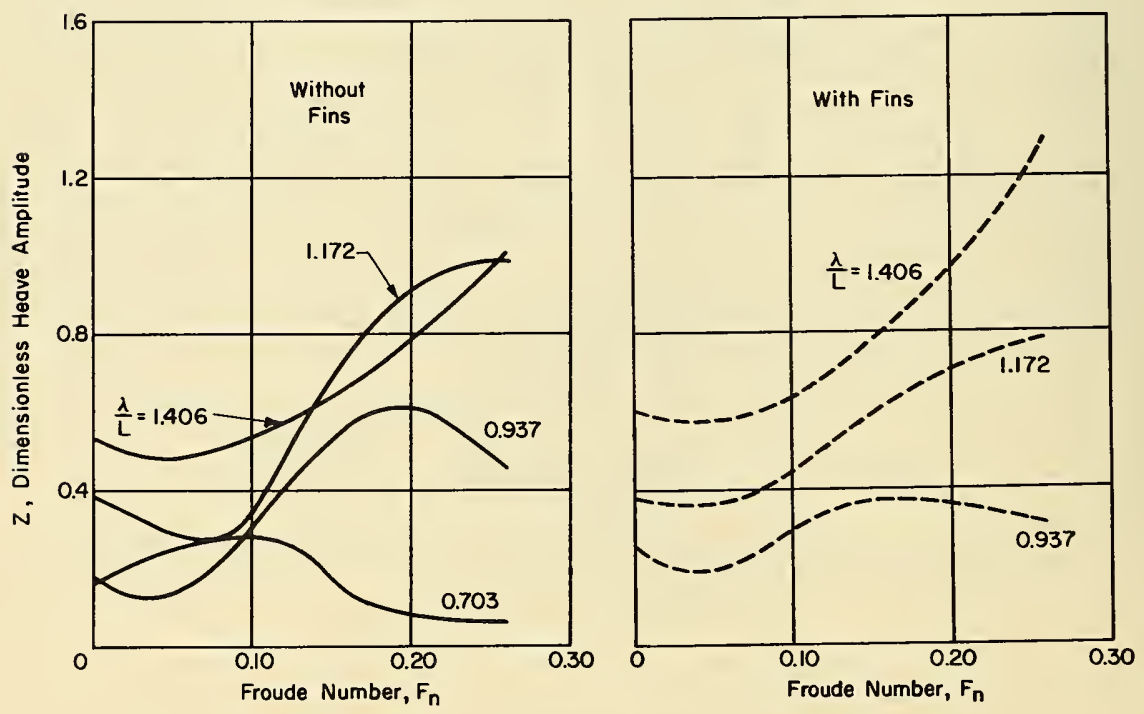

Figure 17 - Dimensionless Heave Amplitudes 

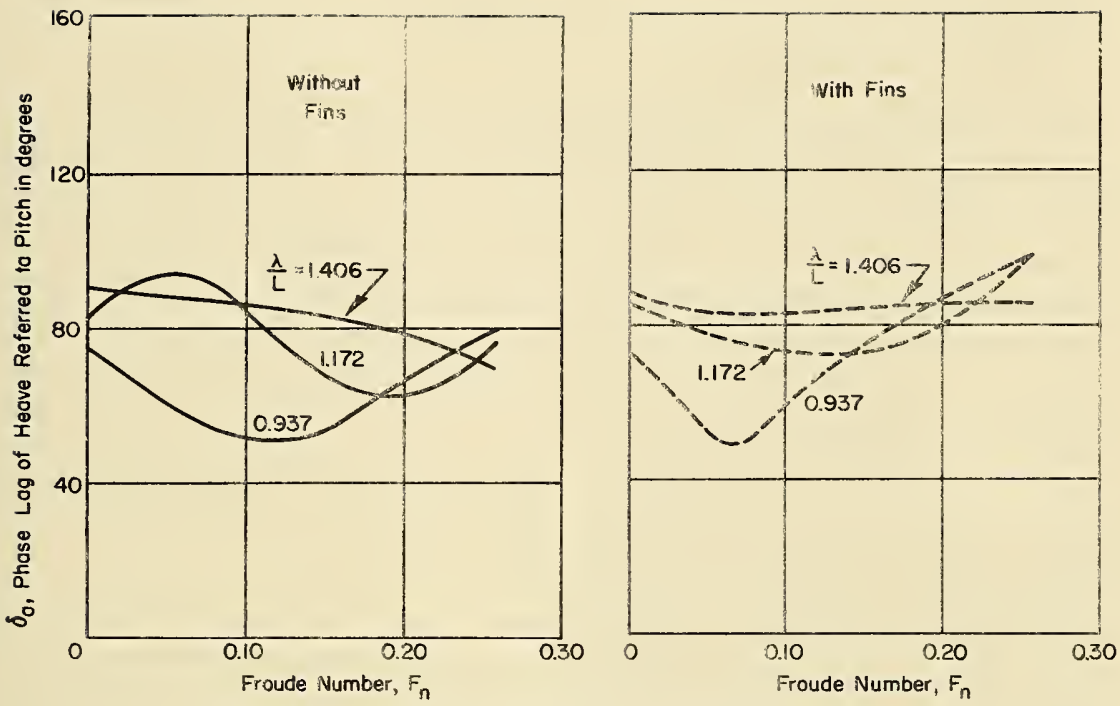

Figure 18 - Phase Lag of Heave Referred to Pitch

of the comparative performance of the various fin configurations is presented under "Discussion of Results."

\section{SUMMARY OF TEST RESULTS (Figures 16 through 18)}

The test data are summarized graphically in Figures 16,17, and 18, presenting pitch, heave, and phase angles, respectively, for the Mariner-type ship with and without antipitching fins.

\section{DISCUSSION OF RESULTS}

The results of the model tests indicate the feasibility of reducing the amplitude of pitch of the Mariner by means of antipitching fins installed at the bow of the ship. The numerical value of the full-scale pitch reduction, however, may be influenced by scale effects.

The tests at the lighter load conditions, corresponding to 15,870 tons and mean draft of 23 feet with 4-foot trim by the stern, showed small differences of pitch and heave amplitudes compared with the results of the tests at the heavier load condition. The general behavior of the model in the regular tank waves was, however, much worse in the lighter condition. Forefoot emergence and slamming occurred frequently. This can be attributed to the shallow draft of 21 feet forward, and possibly unfavorable phase relationship between the heaving and 
pitching motions. The experimental data of the light load tests were not analyzed to the extent required for careful conclusions.

An important effect of fitting antipitching fins was the elimination of slamming in the conditions tested. Slamming of the ship without fins in the heavier load condition occurred in wave lengths near ship length, and at speeds between 10 and 20 knots. The effect of the fins was to maintain a minimum forefoot submergence of ahout 9 feet, in waves up to ahout 1.2 times the length of the ship. However, fin skimming and emergence did occur at the longer wave lengths. Skimming of the fins apparently caused no visible violence. Emergence, when referred to the uninterrupted wave surface, was limited to some length forward of the trailing edge of the fins. The whole underside of the fins, though, remained wet from the water drawn by the fins during the up-stroke of the motion. The strain records did not indicate any disproportionate increase in bending moment as might occur during slamming after emergence. This observation, of course, is not conclusive because many factors, such as relative frequencies, have not been considered. The dihedral fin was observed to re-enter the water in a smoother way, compared with the other fins.

The effect of forward speed and wave length on pitch reduction is noteworthy. It will be observed that the damping contributed by the fins attains its maximum effectiveness in reducing the amplitude of pitch when the ship operates in the near-synchronous range. At very low and very high frequencies of oscillation (that is, at frequencies of encounter with the waves far removed from the natural frequency of the ship in pitch) the effects of added damping are generally small.

The fins have little effect on the phase lag of heave after pitch. The small changes of the phase-lag values, however, assume importance in defining the point of minimum motion and also the vertical motion of any point along the length of the ship. Figures 12a through $12 \mathrm{~d}$ of the results show this effect clearly. Although the point of minimum motion changes location with wave conditions and speed, such changes are rather small. For all practical purposes, the apparent pitching axis remains in the vicinity of amidships. The particular fin is seen to cause a comparatively greater shift of the apparent pitching axis mainly in the forward direction. The amplitude of the minimum vertical motion with and without fins is practically identical, except in the longer waves tested. The dominant effect of the fins is to reduce the amplitudes of the vertical motion and acceleration at points away from the apparent pitching axis. This effect cannot be overlooked when installing equipment that has operational acceleration limitations.

Figure 15 shows that the reduction of the pitching motion by the various configurations was practically the same. Some differences exist in the 600-foot wave length, but they are too small to assume significance. It can be concluded that the plan area of the fin is an important factor in pitch reduction. However, the effectiveness of antipitching fins can be also improved by designing for a higher vertical drag coefficient. The effect of area on the antipitching effectiveness of the fins may be brought out by comparing Fins No. 2, $2 s$, and 4. 
Fin No. $2 s$, having the smallest plan area, shows reductions comparable to Fin No. 2. On the other hand, Fin No. 4, having the largest plan area, does not show any added improvement.

In establishing the geometry of the fins, one must take into account the vorticity generated by their motion. This arises from the pressure differences between the upper and the lower surfaces of the fin. Such vorticity can result in structural damage, such as recently experienced by a Dutch liner.

It appears from observations during the tests that the severity of the hydrodynamic loading imposed on the hull by the vortices shed by the fins can be lessened by:

1. Deeper submergence of the fins (Fin No. 4).

2. Greater fin span (Fin No. 1).

3. Tip fences.

4. Relief mechanisms such as slots and holes (Fins No. 2, 4, 2h, and $4 h$ ).

To provide a basis for structural design, hydrodynamic bending moments were measured at one point along the span (Fin No. 1) corresponding to 7 feet off the centerline, full scale. These are shown in Figure 15 as a function of ship speed, wave length, and wave height.

In regard to the strength of the fins, the bending moments presented in Figure 14 should be treated with caution. Since the load distribution is unknown, it is not possible to derive the values for the bending moment at the root. Theoretical slamming computations, however, indicate that the bending moment due to slamming is higher than that predicted for the quasisteady state. Thus, the structural design of the fin should be based on loads experienced during slamming. The dihedral fin was observed to be the smoothest of the various configurations tested in respect to re-entering after emergence in the most severe wave conditions tested.

\section{CONCLUSIONS}

The results of the model tests indicate that reduction of the pitching motion of the Mariner ship can be obtained by means of fixed antipitching fins installed at the bow.

\section{REFERENCES}

1. Pournaras, U.A., "Pitch Reduction with Fixed Bow Fins on a Model of the Series 60 , 0.60 Block Coefficient," David Taylor Model Basin Report 1061 (Oct 1956).

2. Szebehely, V.G., "Apparent Pitching Axis," Forschungshefte fü Schiffstechnik, Vol. 3, No. 16, p. 184 (1956). 



\section{CNITAL DISTRISUTION}

Copies

13 CHBUSHIPS, Tech Library (Code 3i2)

5 Tech Library

1 Tech Asst to Chiel (Code 105)

1 Appl Science (Code 370)

1 Ship Design (Code 410)

1 Prelim Des Br (Code 420)

1 Submarines (Code 525)

1 tunesweeping (Code 631)

1 Torpedo Counlemeasures (Code 631 M)

2 CHBUORD

1 Code ReD 3

1 Code ReD

2

CHBUAER, Aero \& Hydro Br (Ad-3)

5 CHONR

1 idalh $3 r$ (Code 432)

2 ilech Or (Code 438)

1 Naval Sciences Div (Code 460)

1 Undersea fiarfare Bı (Code 466)

$1 \mathrm{CO}$, ONR, New York, N. Y.

1 C0, ONR, Nayy No, 100, FPO Box 39 , London, England

1 NAVSHIPYD NORVA

1 NAVSHIPYD BSN

1 NAVSHIPYO PTSMH

1 NAVSHIPYO PUG

1 CO, SURASDEVDET, Key Wesl, Fla.

1 COR, USNDL

1 DIR, USNRL

1 DIR, Langley Aero Lab, Langley Field, Va.

1 CDR, USN Air Missile Ctr, Point Hugu, Calii.

1 CDR, USNOTS, Underwater Ord Div, Pasajena, Calil.

1 COR, USNOTS, China Lake, Calit.

1 CO, USNuDL, Panama City, Fla.

1 CO, USNUOS, Newport, R.I.

1 CO, Frankford Arsenal OHice of Air Res, Appl "Wech $\mathrm{Gr}$, Wright-P allerson AFB, 0 .

1 DIR, Nall BuStand

1 BAR, Bendix Avialion Corp, Teterioro, N.J.

10 ASTIA, TIPDR, Artinglon, Va.

1 Asst Secy ol Det (Res \& Ëngin)

1 DIR, Alden Hydra Lab, Helnrcester Polytech Insl, Worcester 2, Mass.

1 DIR, Appl Phy Lab, Johns Hopkins Univ, Silver Spring, $4 \mathrm{~d}$.
Copres

1 DiR, Fluid "iech Lab, Columbia iniv, Hew York, N. Y.

1 is IR, Fiuid Mech Lab, Jrus of Calif. Berheley, Calit.

3 DLR, ETT, SIT, Hoboken, N.J. 1 E.V. Lewis 1 Cr. B.V. Korvin-Kroukousky

1 DiR, Exptl Mav Tank, Univ ol Mich, Ann Acbor, Sich.

1 OIR, Inst for Fluid Dyoarsics \& Apsi wath, Univ of Maryland, College Park,

i DiR, Hydra Lat, Univ ol Colorado, Coulder, Colo.

1 DiR, Hydra Res Lab, Univ of Conan, Stors, Conn.

$10 t R$, Scripps last of Oceanograpby, Univ of Calit, Lalolla, Calit.

1 DIR, Fluid Nech Lab, New York Iniv, New York 53, N.Y.

1 OIR, Robinson Hyura Las, Ohio St Univ, Coluenbus, 0 .

1 OIR, Hydra Lab, Penn State Univ, University Park, $\mathrm{Pa}$.

$13 \mathrm{AR}$, Woods Hole Dceanographic inst, Hoods Hole, Mass.

1 DIR, Mydra Lab, Univ of trisconsin, Madison 6, His.

1 DIR, Hydra Lib, Univ of Washington, Sealtle 5, Wash.

1 DIR, ORL, Penn St Univ, Universily Park, $\mathrm{Pa}$.

1 Idmin, Webb Inst al Nav Aich, Gien Cove, Lamg Island, H.Y.

2 DIR lowa Inst of Hydla Res, SI Univ of lowa. lowa City, lowa 1 Vr. L. Landweber

1 DIR, 3I. Anlhony Falls Hydra Lab, Univ of Atnnesota, Pinneapolis, Minn.

1 OIR of Res, The Tech inst, Norihwestem Univ, Evaustan, III.

1 Head, Dept MAME, INIT, Canbridge 39 , Mass.

1 Editor, Bibliography of Tech Fegorls, Office of Tech Services, US Dept of Competce, Jashinglon 25, D.C.

1 SUPSHIPINSORD, Quincy 69, tass.

3 Nevport News Shipbldg \& Dry Dock Co, Newport News, Va 1 Asst Naw Arch 2 OIR, Hydra Lab

2 SUPSHIPINSORD, New York Shiphidg Corp. Canden, N.). 1 Mr. 1.7. Thompsab, Mav Afrch (Design)
Conies

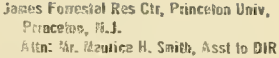

Terty Oir, Ship SIructural Cow, Raul Res C6 ancil, Jashing:on 25, D.C.

2. Dr. S.L. Alberisen, Head of Flest Mech Res, Dest of Ciril Engr, Colorado St Univ, Forl Collins, Coic.

Pry. 14. A. Áskowitz, 94T, Casbridge 39, Mass.

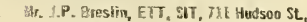
Fisioken, A.J.

1 Dr. George C. PAanving, Prof Niav Aich, tait, Gambridge 39, Rỉass.

3 Prot. F.M. Lewis, Dept MANE, MT, Carebridge 39, Mass.

( DE. R.T. Koapp, Kydro Lab, CIT, Pasadeaa 4, Cotif.

8. ALUSNA, Landon, England

Dine, Hydro Lat, Hall Res Cenacil, Ditawa 2 , Canada

i. Dif. lieorg Hennblen, Universitaet Hanborg, Eeriner Tor 21, Gemany

I B.A.w R. Brand, Direcleur, Bassin d'Essais des Carenes, 5 8ouleward Victor, Faris (15e), France

1 Do. Balavan, Ofice Natienal d'Etwites et Je Recherches Aeronaolinuses, 25-39 Amenue de la Divisiun - LeCleve, Chatillon sius - Bagneux (Senne) LC, Paris, Fraoce

I Tan. Ing. U. Pugliese, Presidenza, Istituta prazionaie per Studi ed Experienze di Archilettara Navale, Via della Yasta Pudvale 59, Roza-Sede, lity

1 Semr Manuel Lopez-म̈cevedo, Qireclot, Canal de Experiencias Hidrodmamicas. El Pando, (Hadrid) Cartelera te la Siena, Spain

1 Dr. J. Dieudonne, Directeor, Instritut de Recherches de la Consiruction Navale, 47, roe de Ploacean Paris (8). France

2 Dir, Nedellandsh Scheecosbooviruadig Proelstation, Barasteeg 2, Raprougen, The Netherlands 1 i. G. Vossers

1 Prol. S.K. Lunde, Starens Skipsmadeltanken, Tyholt, Trandheim, Ronw

1 Dr. Hans Edsbany, Oir, Stateas Skeppsprovningsanstalt, Goleborg C. 14, Gillbraltargatan, Sweden

2 Dir, British Shiphtug Res Assec, 5 Chesterfield Gardens, Carzon St, Londoa is, 1, Eagland

1 Supl, Ship Div, Narional Pby Lab, Teddington, Uiddlesex, England

1 [4. 3. Okabe, Fes Inst Ior Mppl "iech, Iyusho Univ, Hakozaki-13achi, Fokuoka-shi, Japan 
Copies

1 Chief Supt., Maval Res Esiablishmeut

c/o Fleef Maih Ottice, Halotax

Nova Scotia, Caaada

1 Prof. L. Howarth, Dept of Math, Univ of Bristol, Bristot, England

1 Ir. J. Geritsoa, Delft Shipòldg Lab̀, Prof. Meleiweg, Delft, The Hetherlands

1 Dr. Siegfried Schusfer, Head, Bertin Model Basis Versuchsanstalt hu Rasserbas and Schiffban, Schleaseninsel in Tierzarter, Berlie 87, Germany

1 Dr. H.E. Lerbs, Dir, Hanburg Vodel Basie, Hambergische Schiffbaw-Versechsanstalt, Bramfelder Str. 164, Hamberg 33, Gernaoy

2 Dit, Adwirality Experiment Borks, Gosport, Hants, Englant

1 Er. E.C. Twpper

1 D.. V.G. Szehehely, General Electric Co, 3198 Chesturt SI, Philadelahia 4, Da.

1 Prof. C.W. Prohaska, Ship Model Basie. Hịorteizaersvej 99, K/ampeahorg, Deamar's

1 Di. Aldo Aedreoni, Instituto de Pesqiusas Techncolocgicas, Caira Pastal $\boldsymbol{\gamma} 141$, Sa Paolo, Brazil 


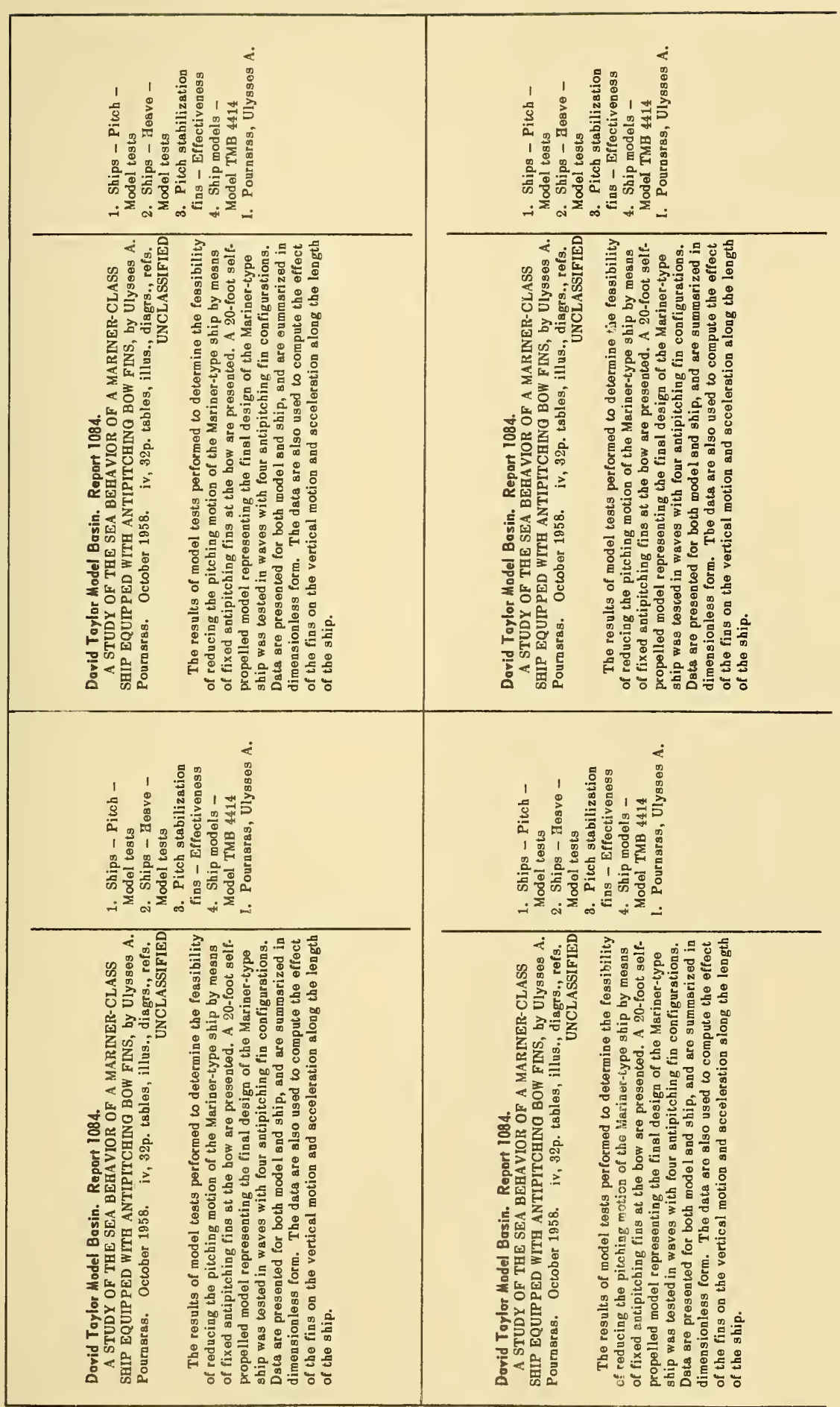






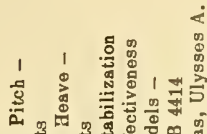

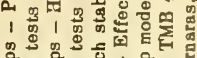

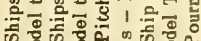

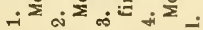

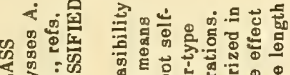

它方药 要

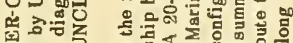

起皆总

$<0$ in

$<0$

\& 0

跳西

$5 \geq 0$

8 붕

回点

cंख

约四

由톤

홉표용

물동

하슬

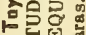

일

高靁高

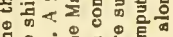

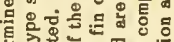

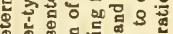

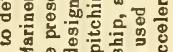

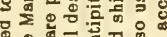

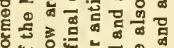

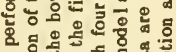

忽争

So

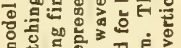

E.

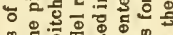

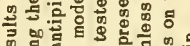

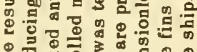

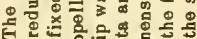

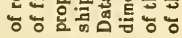

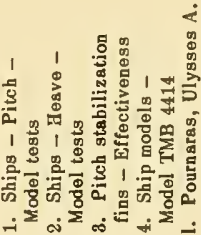

<ं

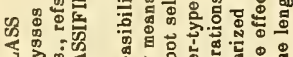

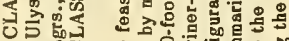

象

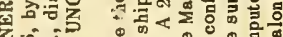

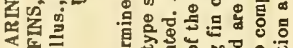

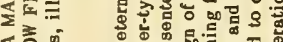

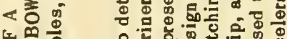

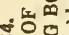

ơ

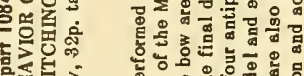

웅른

\&용혀용

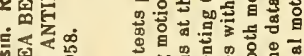

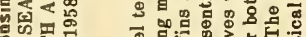

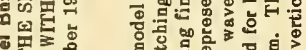

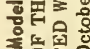

कै द

흥능

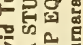

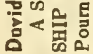

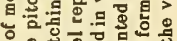

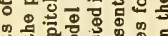

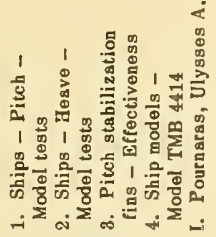

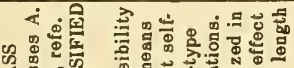

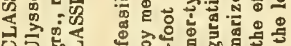

U.

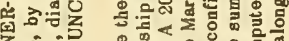

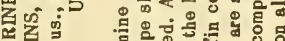

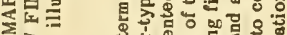

<言向 की

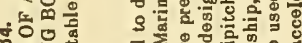

品品

응형

능은

我

E⿺廴⿻肀二𠃋

돔

乘国

옵

皆曷

흐늘

층영

눙

운을

웅중

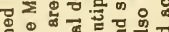

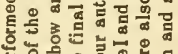

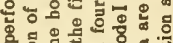

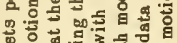

要曋

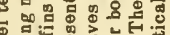

웅

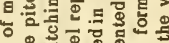

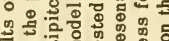

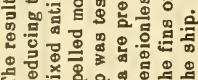

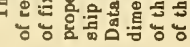

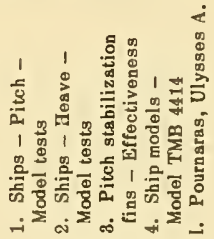

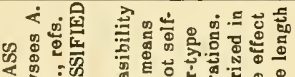

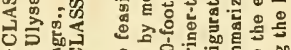

更

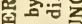

证:

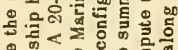

졸

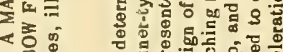

约

象

9.

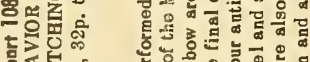

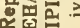

要

.

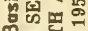

온

둥

高究

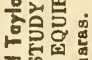

눙

는

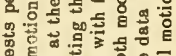

ฮ $\varepsilon$ 品

ब․ㅠ.

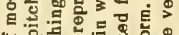

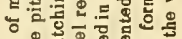

号起空:

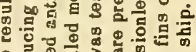

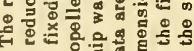




